Article Type: Review

Is it possible to make a diagnosis of raw, heated and baked egg allergy in children using cutoffs? A systematic review

Authors: Calvani Mauro, $\mathrm{MD}^{1}$, Arasi Stefania, $\mathrm{MD}^{2}$, Bianchi Annamaria, $\mathrm{MD}^{3}$, Caimmi Davide, $\mathrm{MD}^{4}$, Cuomo Barbara, $\mathrm{MD}^{5}$, Dondi Arianna, $\mathrm{MD}^{6}$, Indirli Giovanni Cosimo, $\mathrm{MD}^{7}$, La Grutta Stefania, $\mathrm{MD}^{8}$, Panetta Valentina ${ }^{9}$, Verga Maria Carmen, $\mathrm{MD}^{10}$

\title{
Affiliations:
}

${ }^{1}$ Operative Complex Unit of Pediatrics, S. Camillo-Forlanini Hospital, Rome, Italy

${ }^{2}$ Department of Pediatrics, University of Messina, Messina, Italy

${ }^{3}$ Operative Complex Unit of Pediatrics and Neonatal Patology, Mazzoni Hospital, Ascoli Piceno, Italy

${ }^{4}$ Pediatric respiratory diseases Unit of the Department of Pediatrics, Allergy Unit of the Department of Respiratory Diseases, University Hospital of Montpellier, France

${ }^{5}$ Operative Complex Unit of Pediatrics, Hospital of Belcolle Viterbo, Italy

${ }^{6}$ Pediatric Unit, Ramazzini Hospital, Carpi (MO), Italy

${ }^{7}$ Operative Unit of Pediatric Allergy, San Giuseppe da Copertino Hospital, Copertino (LE), Italy

${ }^{8}$ Institute of Biomedicine and Molecular Immunology, National Research Council, Palermo, 90100 Italy

${ }^{9}$ L'altrastatistica srl, Consultancy \& Training, Biostatistics office, Rome, Italy

${ }^{10}$ Primary Care Pediatrics, ASL Salerno, Vietri sul Mare (SA), Italy

Running title: Reviewing SPTs and IgEs cut-offs for egg allergy

Corresponding Author: Davide Caimmi, CRCM et Service d'allergologie, CHRU de Montpellier, Hôpital Arnaud de Villeneuve, 371, Av. du Doyen Gaston Giraud, 34295 Montpellier CEDEX 5, tel : +33630061134, fax : +33467330740, e-mail : davide.caimmi@gmail.com

This article has been accepted for publication and undergone full peer review but has not been through the copyediting, typesetting, pagination and proofreading process, which may lead to differences between this version and the Version of Record. Please cite this article as doi: $10.1111 /$ pai.12432

This article is protected by copyright. All rights reserved. 


\section{Abstract \\ Is it possible to make a diagnosis of raw, heated and baked egg allergy in children using cut- offs? A systematic review}

Pediatr Allergy Immunol

Background. The diagnosis of IgE-mediated egg allergy lies both on a compatible clinical history and on the results of skin prick tests (SPTs) and IgEs levels. Both tests have good sensitivity but low specificity. For this reason, oral food challenge (OFC) is the ultimate gold standard for the diagnosis. The aim of the present paper is to systematically review the literature in order to identify, analyze and synthesize the predictive value of SPT and specific IgEs both to egg white and main egg allergens and to review the cut-offs suggested in the literature.

Methods. A total of 37 articles were included in this systematic review. Studies were grouped according to degree of cooking of the egg used for OFC, age and type of allergen used to perform the allergy work-up.

Results. In children $<2$ years, raw egg allergy seems very likely when SPTs with egg white extract are $\geq 4 \mathrm{~mm}$ or specific IgEs are $\geq 1.7 \mathrm{kU} \mathrm{A}_{\mathrm{A}} / \mathrm{L}$. In children $\geq 2$ years, OFC could be avoided when SPTs with egg white extract are $\geq 10 \mathrm{~mm}$ or Prick by Prick with egg white are $\geq 14 \mathrm{~mm}$ or specific IgE are $\geq$ $7.3 \mathrm{kU}_{\mathrm{A}} / \mathrm{L}$. Likewise, heated egg allergy can be diagnosed if SPTs with egg white extract are $>5 \mathrm{~mm}$ and $>11 \mathrm{~mm}$ in children $<2$ years and $\geq 2$ years, respectively.

Conclusions. Further and better-designed studies are needed to determine the remaining diagnostic cut-off of specific IgE and SPT for heated and baked egg allergy.

Key Words: egg, cut-off, skin prick test, specific IgE, oral food challenge

The Authors have no conflict of interest to declare for the present paper.

\section{Introduction}

Hen's egg is a vital source of proteins and lipids and is widely consumed worldwide in different ways. Egg allergy is one of the three main food allergies in pediatrics and its prevalence ranges between 1.6 and $8-9 \%(1-4)$.

This article is protected by copyright. All rights reserved. 
According to a European study, egg is the main cause of food allergy in children aged 5 months to 15 years, being highlighted in $35.7 \%$ of subjects (5). The importance of egg allergy is also underlined by two recent collaborative Italian studies: egg was the most frequently evaluated food in a cohort of 544 oral food challenge (OFC) (6) and it is the second allergen, besides cow's milk proteins, related to food anaphylaxis in pediatrics (7).

The diagnosis of IgE-mediated egg allergy lies on a compatible clinical history and on both the results of skin prick tests (SPTs) and the determination of serum specific Immunoglobulins E (sIgEs). Both tests have good sensitivity but low specificity, which means that they are often positive in non-allergic subjects (8). Therefore, if a diagnosis was based on the positivity of such tests only, a group of sensitized subjects would uselessly undergo an egg-free diet. For this reason, OFC is the ultimate gold standard for the diagnosis of egg allergy, despite the difficulties due to cost, commitment and, above all, risk for the patient to develop a potentially severe anaphylactic reaction during the test.

It is well known that the greater the SPTs wheal size or the sIgEs level, the greater the probability to show allergic symptoms $(9,10)$. For such a reason, many authors tried to determine a cut-off for wheal sizes or for sIgEs levels able to predict with the highest probability a positive egg challenge $(11,12)$.

The aim of the present paper was to systematically review the literature in order to identify, appraise and synthesize the predictive value of SPTs and specific IgEs both to egg white and to main egg allergens (ovoalbumin, OVA, and ovomucoid, OVM). We also tried to review the cut-offs suggested in the literature, in order to provide practical clinical indications for the diagnosis of egg allergy in children.

This article is protected by copyright. All rights reserved. 
Several studies showed that cut-off values might vary with the degree of cooking of the egg used for the oral food challenge $(13)$, with age $(14,15)$ and with the type of allergen used to perform SPTs (commercial extract, raw or heated egg) $(6,16)$. Thus, in the present review we grouped studies according to these three factors.

At the best of our knowledge, such a classification has never been taken into account in previous reviews $(15,17)$, guidelines or international consensus $(18,22)$ published on this subject.

\section{Methods}

\section{Search strategy}

A comprehensive search was conducted on December 2014 on MEDLINE literature via PubMed and Scopus. Citations were identified on the electronic databases using the terms "SPT" or "skin prick test" or "specific IgE" and "egg allergy" or "egg hypersensitivity".

To reduce the risk of losing relevant studies, searches were not restricted by publication type or study design. Relevant retrieved articles, reviews and clinical studies published on this topic were included as well, even though not highlighted by our initial search (20-25).

All these studies were assessed, discussed in details and evaluated for quality by the authors in a standardized independent way.

\section{Inclusion and exclusion criteria}

We included studies in which authors looked for a cut-off value for SPTs or sIgEs levels for the diagnosis of egg allergy. In most of the included study, diagnosis was based on OFC. We also included studies in which diagnosis, based on a clear relationship between egg exposure and allergic reaction, was recently highlighted with a positive test (SPTs and/or sIgE levels).

This article is protected by copyright. All rights reserved. 
Studies were excluded if information on food allergy was not specific for egg allergy only. Studies were also excluded whenever the results only pointed out the optimal cut-off (best criterion for sensitivity and specificity optimization), which is not sufficient to select children at high risk of allergic reactions during an OFC.

\section{Methodological quality of the included studies}

The methodological quality of the included studies was evaluated according to the criteria given by the QUADAS-2 tool (26). Five reviewers appraised studies to assess the risk of bias. Two different authors independently reviewed each article. Any discrepancies were resolved by consensus between all reviewers.

\section{Results}

The search run on the electronic databases produced 469 results in Pubmed and 348 in Scopus. Four hundred and seventeen studies found on Pubmed and 312 found on Scopus were immediately excluded because they tested for allergens other than egg or were oral immunotherapy trials or did not quantify the association between SPTs wheal size or specific IgE and the risk of egg allergy. The remaining 52 and 36 articles from each database respectively were assessed as to whether they met the inclusion criteria and 35 papers were finally included in this review. After a manual search of the references, a total of 37 articles were included in this systematic review (Figure 1).

These studies are hereby presented separately, grouping them on the basis of SPTs wheal size or

sIgEs. Then they were further grouped according to the cooking degree of egg administered during OFC into three groups that are:

a) raw: raw egg was administered for the OFC (or dehydrated egg, for which an allergenicity identical to raw egg was demonstrated) $(27,28)$;

This article is protected by copyright. All rights reserved. 
b) heated: lightly boiled or scrambled (regular) egg was administered for the $\mathrm{OFC}\left(\leq 100^{\circ} \mathrm{C}\right.$ or $212^{\circ} \mathrm{F}$, usually for few minutes);

c) baked: extensively heated egg was administered for the $\mathrm{OFC}\left(>100^{\circ} \mathrm{C}\right.$ or $212^{\circ} \mathrm{F}$, usually for many minutes).

Those studies proposing cut-offs, but not differentiating the results on the basis of different degrees of eggs cooking were excluded from the analysis $(6,29-34)$. Data from these studies are reported in supplementary tables.

Figure 2 summarizes the methodological quality of the 37 included articles. Most articles were judged to be at high risk of bias and applicability as for patients' selection. Many studies showed high or unclear risk of bias as for flow and timing and high or unclear risk of bias and applicability as for reference standards. All studies were judged to be at low risk as for the index test.

\section{SPT predictive value}

19 studies assessed the diagnostic efficacy of SPTs with egg white or egg allergens. 4 studies have proposed cut-offs without distinguishing the degree of eggs cooking $(6,29-31)$. They were therefore excluded from the analysis (Table s1). The remaining 15 studies were grouped according to the cooking degree of egg administered during the OFC. Two studies $(16,35)$ proposed cut-offs for different cooking degrees of egg, and are therefore included in each group.

\section{a) Egg SPTs predictive value and cut-off for raw egg allergy diagnosis}

6 studies evaluated the predictive value of SPTs using commercial extracts or Prick by Prick $(\mathrm{PbP})$ with raw egg by OFC with raw egg $(11,12,16,35-37)$. Five $(11,16,35-37)$ out of six were prospective studies and three out six were $\operatorname{DBPCFC}(11,12,35)$. One (37) out six studies showed a low risk of bias according to QUADAS-2. Studies differ in allergy prevalence, statistic analysis, type

This article is protected by copyright. All rights reserved. 
of cut-off, criteria to define a positive OFC, and type of allergen used to perform the SPTs (commercial extract or raw egg). All these factors could contribute to explain the difference between the proposed cut-off values, which range between 4 and $14 \mathrm{~mm}$ for egg white.

However, differences between the proposed cut-off values are notably reduced when differentiating the type of allergen used to perform the SPTs and the age of the included population (Table 1a and 1b).

Indeed, in children younger than 2 years, two studies showed quite similar cut-offs ( $4 \mathrm{~mm}$ and $5 \mathrm{~mm}$ ) $(16,36)$ whereas in children aged 2 years or older the other two studies showed quite different cutoffs $(6 \mathrm{~mm}$ and $10 \mathrm{~mm})$, the greater in the study enrolling a population with an older mean age (35, 37). Moreover, one of these last two studies (37) used more conservative criteria to define a positive

OFC. In fact, OFC was considered as positive when an immediate reaction involved at least two organs. Also, the type of selected cut-off was very different (100\% PPV and 70\% specificity vs. $80 \%$ PPV and $95 \%$ specificity).

When fresh hen's egg is used to perform $\mathrm{PbP}$, two studies showed quite similar cut-off (13 and 14 $\mathrm{mm})(11,12)$. Even if one (12) of these studies was a prospective one, both were at high risk of bias according to QUADAS-2.

Only one study (35) proposed a 95\% specificity cut-off for ovoalbumin and ovomucoid of $10 \mathrm{~mm}$ and $8.5 \mathrm{~mm}$, respectively.

\section{b) Egg SPTs predictive value and cut-off for heated egg allergy diagnosis}

Two studies proposed a cut-off for heated egg allergy $(35,38)$. Both were prospective studies, and in one the authors run a DBPCFC. Both studies were judged at risk of bias (Table 2). Only one study

This article is protected by copyright. All rights reserved. 
(38) proposed a $100 \%$ specificity cut off for egg white of $5 \mathrm{~mm}$ and $7 \mathrm{~mm}$ in children respectively younger and older than 2 years. The other study (35) proposed a 95\% specificity cut off in children over two years for egg white, ovoalbumin and ovomucoid of $11 \mathrm{~mm}, 10.5 \mathrm{~mm}$ and $13 \mathrm{~mm}$, respectively.

\section{c) Egg SPTs predictive value and cut-off for baked (extensively heated) egg allergy diagnosis}

9 studies were included in this group $(16,39-46)$. None of them was a DBPCFC study and only four were prospective studies $(16,39,43,45)$. All studies were judged at risk of bias in one or more domains. There were also differences between cooking time and temperature and the amount of egg used.

Six studies $(16,39,41-44)$ evaluated the diagnostic efficacy of the commercial extracts; two $(45,46)$ of Prick by Prick $(\mathrm{PbP})$ performed with muffin containing baked egg; and one study (40) assessed both commercial extract and PbP. The main features of the studies are shown in Table 3.

Among these 9 studies, four studies were able to find diagnostic cut-off values for egg white $(16,40$, $41,43)$ and only one study suggest a diagnostic cut-off for ovomucoid (45).

One study only enrolled children younger than 2 years (16). In this prospective study, Peters reported that "no SPT threshold had a 95\% PPV for baked egg"; however, an 82\% PPV was calculated at 11 $\mathrm{mm}$. The area under the curve (AUC) was low (0.65), and therefore SPTs are poor predictors of baked egg allergy (16). The remaining studies (39-46) were conducted in children older than two years. They were all considered at high risk of bias and proposed different cut-offs. In the first study (40), Turner also demonstrated that children who reacted to baked egg had a larger SPT wheal to both commercial extract SPT (median $8 \mathrm{~mm}$ ) and raw egg (median $12 \mathrm{~mm}$ ) compared to baked-egg

This article is protected by copyright. All rights reserved. 
tolerant children, median $5 \mathrm{~mm}$ and $10 \mathrm{~mm}$, respectively $(\mathrm{p}<0.001)$. However, the ROC curve analysis demonstrated poor predictive ability, with an AUC for commercial extract and raw egg SPTs equal to 0.71 and 0.63 , respectively. In this study, the cut-off value of $12 \mathrm{~mm}$ for commercial extract and of $20 \mathrm{~mm}$ for raw egg demonstrated $98 \%$ and $95 \%$ specificity, respectively (40). In the second study (41), Bartnikas showed that SPT wheal size was significantly higher in children allergic to baked egg (median $13 \mathrm{~mm}$ ) in comparison to those who tolerated it (median $9 \mathrm{~mm}$ ). The cut-off value with a specificity of $95 \%$ for allergy to baked egg was $25 \mathrm{~mm}$ (41). Lemon-Mulè showed that a SPT wheal size of $15 \mathrm{~mm}$ of diameter only had a $60 \%$ PPV for heated egg allergy (43). Finally, in the study of Tan (45), a SPT wheal size with OVM of $11 \mathrm{~mm}$ represented the diagnostic cut-off value, with a PPV of $100 \%$. No diagnostic cut-off for PbP containing baked egg were found in two studies $(45,46)$.

\section{Specific IgE predictive value}

30 studies examined the diagnostic efficacy of specific IgE to egg white or egg allergens toward egg allergy diagnosis confirmed by OFC. Six studies proposed cut-offs without distinguishing the results of the OFC on the basis of different degrees of eggs cooking (29-34), as shown in Table S2. The remaining 24 studies were divided according to the cooking degree of the egg administered during the OFC.

\section{a) Predictive value of specific IgEs to egg white, ovoalbumin or ovomucoid and cut-offs for raw egg allergy diagnosis}

14 out 24 studies performed an OFC with raw or lyophilized egg $(9,12,16,35-37,47-54)$. Eight out of 14 were prospective studies $(12,16,35-37,49,52,53)$ and 7 out of 14 were $\operatorname{DBPCFC}(9,12,35$, $49,50,52,53)$.

This article is protected by copyright. All rights reserved. 
According to QUADAS-2, three $(37,47,51)$ out of 14 studies were at low risk of bias and four $(9,48$, $50,52)$ were at unclear risk of bias. The main features of these studies are shown in Table 4.

These studies are quite different for relevant variables, such as allergy prevalence, diagnostic methodology, statistical analysis, and type of proposed cut-off. All these factors could contribute to explain the differences between the proposed cut-off values.

Three studies enrolling children aged less than 2 years proposed very different cut-offs for egg white $(16,36,48)$. Two were open prospective studies: the first (36) proposed a $100 \%$ specificity cut-off of $>99 \mathrm{kU}_{\mathrm{A}} / \mathrm{L}$, the second (16) a $95 \%$ PPV cut off of $1.7 \mathrm{kU}_{\mathrm{A}} / \mathrm{L}$. One (47) was a retrospective study and proposed a $100 \%$ PPV with a cut-off of $1.5 \mathrm{kU}_{\mathrm{A}} / \mathrm{L}$.

12 studies enrolled children aged more than 2 years $(9,12,35,37,47-54)$. All these studies also were at risk of bias according to QUADAS-2. The proposed cut-offs proposed for egg white range between $1.3 \mathrm{kU}_{\mathrm{A}} / \mathrm{L}$ and $75 \mathrm{kU}_{\mathrm{A}} / \mathrm{L}$. In this group, five were prospective DBPCFC studies $(12,35,49,52,53)$, and proposed a cut-off ranging between $3.7 \mathrm{kU}_{\mathrm{A}} / \mathrm{L}$ and $17.5 \mathrm{kU}_{\mathrm{A}} / \mathrm{L}$.

Two $(50,52)$ out of the total 14 studies reported the diagnostic efficacy of molecular allergens as well. Ott et al. demonstrated that specific IgEs to OVM, determined through ISAC®, have a PPV for a positive OFC with raw egg comparable to egg white IgEs and SPTs. The study did not propose any diagnostic cut-off value (50). Ando et al. identified a cut-off value of $9.8 \mathrm{kU}_{\mathrm{A}} / \mathrm{L}$ for OVA and of 5.2 $\mathrm{kU}_{\mathrm{A}} / \mathrm{L}$ for OVM as predictive of an allergic reaction to raw egg, with a 95\% PPV (52). This study was judged at unclear risk of bias only for flow and timing-

This article is protected by copyright. All rights reserved. 


\section{b) Predictive value of specific IgEs to egg white, ovoalbumin or ovomucoid and cut-offs for heated egg allergy diagnosis}

Five $(35,52,55-57)$ out of 24 studies performed an OFC with heated egg. Three $(35,52,55)$ out five were prospective studies and two $(35,52)$ out five were DBPCFC studies. These studies are rather different as for age of the enrolled population, different time of heating, amount of administered egg, and different statistical analysis. They proposed different cut-offs for egg white, ranging from $\geq 24$ $\mathrm{kU}_{\mathrm{A}} / \mathrm{L}$ to $61 \mathrm{kU}_{\mathrm{A}} / \mathrm{L}$ (Table 5). All of these studies were judged at high or unclear risk of bias.

Only two $(35,52)$ out of the three prospective studies were able to provide a diagnostic cut-off. The first (35), conducted by Vazquez-Ortiz et al., proposed a 95\% PPV cut-off for egg white, ovoalbumin and ovomucoid of $4.08 \mathrm{kU}_{\mathrm{A}} / \mathrm{L}, 2.8 \mathrm{kU}_{\mathrm{A}} / \mathrm{L}$ and $3.74 \mathrm{kU}_{\mathrm{A}} / \mathrm{L}$, respectively. The second (52), conducted by Ando et al., proposed a 96\% specificity cut-off for egg white, ovoalbumin and ovomucoid of 30.7 $\mathrm{kU}_{\mathrm{A}} / \mathrm{L}, 29.3 \mathrm{kU}_{\mathrm{A}} / \mathrm{L}$ and $10.8 \mathrm{kU}_{\mathrm{A}} / \mathrm{L}$, respectively.

\section{c) Predictive value of specific IgEs to egg white or egg allergens and cut-offs for baked (extensively heated) egg allergy diagnosis}

Seven studies evaluated the diagnostic efficacy of cut-off values for specific IgEs to egg white or to molecular allergens as compared to an OFC with baked egg (41-44, 58-60). Methodological value was quite low: only three $(43,59,60)$ of these studies were prospective study, none used DBPCFC and all were judged to be at high risk of bias in several domains (Table 6).

Of the three prospective studies $(43,59,60)$, only one (59) proposed a 95\% PPV diagnostic cut-off for egg white and ovomucoid (10 $\mathrm{kU}_{\mathrm{A}} / \mathrm{L}$ and $6 \mathrm{kU}_{\mathrm{A}} / \mathrm{L}$, respectively).

This article is protected by copyright. All rights reserved. 
The cut-offs proposed from prospective studies ranged from $10 \mathrm{kU}_{\mathrm{A}} / \mathrm{L}$ to $26.2 \mathrm{kU} \mathrm{A}_{\mathrm{A}} / \mathrm{L}$ and from 6 $\mathrm{kU}_{\mathrm{A}} / \mathrm{L}$ to $50 \mathrm{kU}_{\mathrm{A}} / \mathrm{L}$ for egg white and ovomucoid, respectively. Only one study (60) proposed a cutoff for ovoalbumin $\left(25.3 \mathrm{kU}_{\mathrm{A}} / \mathrm{L}\right)$.

\section{Discussion}

Several authors, guidelines and international consensus have suggested the use of cut-off values to reach a diagnosis of egg allergy without performing an OFC (20-24). So far, more than thirty articles have addressed this issue and proposed diagnostic cut-offs for egg allergy.

To make these studies as homogeneous as possible, we have grouped them according to the age of the study population ( $<$ or $\geq 2$ years) and to the type of allergen used to perform SPTs. OVA, the most abundant protein found in egg white, is quite sensitive to thermic denaturation, like other egg proteins, such as ovotransferrin and lysozime (61). On the contrary, OVM is relatively resistant to heat and is considered to be the dominant allergen in egg white (62). Thermal treatment may be divided in two types: moist (such as boiling, frying, etc), and dry heat (such as baking, roasting, etc) (63). Moist heat has only a mild effect on egg allergen reactivity, since OVM and OVA can still be detected immunologically despite hard-boiling of egg white $\left(100^{\circ} \mathrm{C}\right.$ for $\left.20 \mathrm{~min}\right)$. Dry heat seems to have a stronger effect on many allergens within egg white, with the exception of OVM, and therefore significantly reduces egg allergen reactivity (64), probably because such a cooking technique requires more time and higher temperatures. Thus, we grouped the studies into three groups: raw, heated $(\leq$ $100^{\circ} \mathrm{C}$ or $\left.212^{\circ} \mathrm{F}\right)$ and baked (extensively heated) egg $\left(>100^{\circ} \mathrm{C}\right.$ or $\left.212^{\circ} \mathrm{F}\right)$.

To appraise the quality and validity of the included studies, we evaluated the design of the study (prospective vs retrospective), the type of OFC (open vs DBPCFC) and assessed studies according to the QUADAS-2 tool.

This article is protected by copyright. All rights reserved. 
Despite the division into groups based on the degree of cooking, age and the type of allergen used to perform the SPTs, with the exception of cut-offs for raw egg, the other proposed cut-offs showed a large variability, especially for sIgEs.

Several reasons might explain such variability:

a) two different kinds of cut-off values were proposed in literature, both for SPT and for sIgEs: those based on a high positive predictive value (95\% PPV) and those based on a high specificity (cut-off values with $95 \%$ of specificity). The first ones, being based on the predictive value, depend on the prevalence of allergy in the studied population and are applicable in allergy centres where it is assumed that the prevalence of food allergy is similar to the one found in the studies providing the values (65). On the contrary, the cut-off values based on $95 \%$ of specificity do not change with the prevalence of the disease in the population and give us the chance to better select the children to test with OFC, given the high risk of a positive challenge. These two kinds of cut-off values could provide different results even in the same study population.

b) the proposed cut-offs may change dramatically, even within the same study population, for small variations in the chosen level of predictive value, especially for sIgEs. For instance, Celik Bilgili showed that egg cut-offs increase from $6 \mathrm{kU}_{\mathrm{A}} / \mathrm{L}$ when considering a $90 \%$ PPV to $12.6 \mathrm{kU}_{\mathrm{A}} / \mathrm{L}$ with a $95 \% \mathrm{PPV}$ to $59.9 \mathrm{kU}_{\mathrm{A}} / \mathrm{L}$ with a $99 \%$ PPV (48).

c) other reasons may be related to patients' selection, criteria to define a positive OFC, SPT devices, etc (17).

This article is protected by copyright. All rights reserved. 


\section{Practical clinical indications}

Given the large variability of the proposed cut-offs, we tried to highlight some practical clinical indications considering, above all, the methodologically best studies (prospective DBPCFC studies) and, whenever it was possible, those with the best QUADAS-2 results. As for raw-egg allergy, 95\% or higher cut-offs for SPT with commercial extracts and with PbP and SIgE in children younger and older than 2 years were identified. As for heated egg allergy, only SPT cut-offs for commercial extract in children younger and older than 2 years were identified. On the contrary, a cut-off value for sIgE for heated egg allergy seems hard to suggest. In fact, the only two prospective studies for heated egg allergy in children older than 2 years suggested very different cut-offs (Table 7). Finally, no cut-off seems advisable for SPT and for sIgEs for baked egg allergy. In fact, the included studies proposed rather different cut-offs. However, it seems likely that children with baked egg allergy have higher SPT wheal sizes and sIgEs than children suffering from raw or heated egg allergy.

It is difficult to explain the greater difficulty in defining cut-offs for specific IgEs for heated egg than for SPTs. The greater range of sIgEs values (from $0.1 \mathrm{kU}_{\mathrm{A}} / \mathrm{L}$ to over $100 \mathrm{kU}_{\mathrm{A}} / \mathrm{L}$ ) compared to SPTs values (from $1 \mathrm{~mm}$ to over $20 \mathrm{~mm}$ ) could be a reason. As for baked egg allergy, the low quality of the included studies may be the cause: no study was prospective nor DBPCFC. Differences in other variables not considered in the studies, and further discrepancies in the degree of cooking, or the presence of other ingredients (matrix effect) may have influenced the results as well.

\section{Conclusions}

No cut-off value by itself may allow a firm diagnosis of raw, heated or baked egg allergy. However, as for raw egg allergy, when SPTs are $\geq 4 \mathrm{~mm}$ (in children $<2$ years) and $\geq 10 \mathrm{~mm}$ (in children $\geq 2$ years) for raw egg white extract, or when $\mathrm{PbP}$ with egg white are $\geq 14 \mathrm{~mm}$, it is necessary to carefully assess the costs and benefits and to determine the necessity to reach a higher diagnostic certainty,

This article is protected by copyright. All rights reserved. 
affordable only through an OFC. Slightly higher cut-offs for raw egg commercial extract (5 $\mathrm{mm}$ and $11 \mathrm{~mm}$ in children $<2$ years and $\geq 2$ years, respectively) may be adopted for heated egg allergy.

As for specific IgEs, raw egg allergy seems very likely if $\operatorname{sgE}$ are $\geq 1.7 \mathrm{kU}_{\mathrm{A}} / \mathrm{L}$ in children aged less than 2 years and, in order to choose a safer cut-off, $\geq 7.3 \mathrm{kU}_{\mathrm{A}} / \mathrm{L}$ in children $\geq 2$ years.

Further and better-designed studies are needed to determine the remaining diagnostic cut-offs of sIgEs and SPTs for heated and baked egg allergy.

\section{References}

1. Eggesbo M, Botten G, Halvorsen R, Magnus P. The prevalence of allergy to egg: a populationbased study in young children. Allergy 2001: 56: 403-11.

2. Rona RJ, Keil T, Summers C et al. The prevalence of food allergy: a metaanalysis. J Allergy Clin Immunol 2007: 120: 638-46.

3. Benhamou AH, Caubet JC, Eigenmann PA, et al. State of the art and new horizons in the diagnosis and management of egg allergy. Allergy 2010: 65: 283-9.

4. Osborne NJ, Koplin JJ, Martin PE et al. Prevalence of challenge-proven IgE-mediated food allergy using population-based sampling and predetermined challenge criteria in infants. $\mathbf{J}$ Allergy Clin Immunol 2011: 127: 668-76.

5. Rancé F. Actualités de l'allergie alimentaire à l'œuf de poule chez l'enfant. In Asthme et Allergies chez l'enfant et l'adolescent. G. Dutau. Ed. Elsevier. 2005: 11-8.

6. Calvani M, Berti I, Fiocchi A, et al. Oral food challenge: safety, adherence to guidelines and predictive value of skin prick testing. Pediatr Allergy Immunol 2012: 23:755-61.

This article is protected by copyright. All rights reserved. 
7. Calvani M, Cardinale F, Martelli A, et al. Italian Society of Pediatric Allergy and Immunology Anaphylaxis Study Group. Risk factors for severe pediatric food anaphylaxis in Italy. Pediatr Allergy Immunol 2011: 22: 813-9.

8. Sampson HA. Update on food allergy. J Allergy Clin Immunol 2004: 113: 805-19.

9. Sampson HA, Ho DG. Relationship between food-specific IgE concentrations and the risk of positive food challenges in children and adolescents. J Allergy Clin Immunol 1997: 100: 444-51.

10. Hill DJ , Heine RG and Hosking CS. The diagnostic value of skin prick testing in children with food allergy. Pediatr Allergy Immunol 2004: 15: 435-441.

11. Verstege A, Mehl C, Rolinck-Werninghaus C, et al. The predictive value of the skin prick test weal size for the outcome of oral food challenges. Clin Exp Allergy 2005: 35: 1220-6.

12. Mehl A, Rolinck-Werninghaus $\mathrm{C}$, Staden $\mathrm{U}$, et al. The atopy patch test in the diagnostic workup of suspected food-related symptoms in children. J Allergy Clin Immunol 2006: 118: 923-9.

13. Leonard SA, Sampson HA, Sicherer SH et al. Dietary baked egg acceletares resolution of egg allergy in children. J Allergy Clin Immunol 2012: 130: 473-80.

14. Hill DJ, Heine RG, Hosking CS. The diagnostic value of skin prick testing in children whit food allergy. Pediatric Allergy Immunol 2004: 15: 435-41.

15. Jarvinen KM, Sicherer SH. Diagnostic oral challenge: procedures and biomarkers. J Immunol Methods 2012: 383: 30-38.

16. Peters RL, Allen KJ, Dharmage SC, et al; for the HealthNuts study. Skin prick test responses and allergen-specific IgE levels as predictors of peanut, egg, and sesame allergy in infants. $\mathrm{J}$ Allergy Clin Immunol 2013: 132: 874-80.

17. Peters RL, Gurrin LC, Allen KJ. The predictive value of skin prick testing for challenge-proven food allergy: a systematic review. Pediatr Allergy Immunol 2012: 23: 347-5.

This article is protected by copyright. All rights reserved. 
18. Clark AT, Skypala I, Leech SC, et al; British society for Allergy and Clinical Immunology. British Society for Allergy and Clinical Immunology guidelines for the management of egg allergy. Clin Exp Allergy 2010: 40: 1116-29.

19. Ebisawa M. Management of Food Allergy in Japan "Food Allergy Management Guideline 2008 (Revision from 2005)" and "Guidelines for the Treatment of Allergic Diseases in Schools" Allergology International 2009: 58: 475-4.

20. Nowak-Wegrzyn A, Amal H, Assa'ad AH, et al. Adverse Reactions to Food Committee of American Academy of Allergy, Asthma \& Immunology. Work Group report: Oral food challenge testing. J Allergy Clin Immunol 2009: 123(Suppl.6): S365-83.

21. Rancé F, Deschildre A, Villard-Truc F, et al; SFAIC and SP2A Workgroup on OFC in Children. Oral food challenge in children: an expert review. Eur Ann Allergy Clin Immunol 2009: 41: 3549.

22. Sampson HA, Gerth van Wijk R, Bindslev-Jensen C, et al. Standardizing double-blind, placebocontrolled oral food challenges: American Academy of Allergy, Asthma \& ImmunologyEuropean Academy of Allergy and Clinical Immunology PRACTALL consensus report. J Allergy Clin Immunol 2012: 130: 1260-74.

23. Martorell A, Alonso E, Boné J, et al; Food allergy committee of SEICAP. Position document IgE-mediated allergy to egg protein. Allergol Immunopathol (Madr) 2013: 41: 320-36.

24. Caubet JC, Kondo Y, Urisu A, Nowak-Wegrzyn A. Molecular diagnosis of egg allergy. Curr Opin Allergy Clin Immunol 2011: 11: 210-5.

25. O'Keefe AW, De Schryver S, Mill J, Mill C, Dery A, Ben-Shoshan M. Diagnosis and management of food allergies: new and emerging options: a systematic review. J Asthma Allergy 2014: 7: 141-64.

This article is protected by copyright. All rights reserved. 
26. Whiting PF, Rutjes AW, Westwood ME, et al. QUADAS- 2: a revised tool for the quality assessment of diagnostic accuracy studies. Ann Intern Med 2011: 155: 529-36.

27. Jurado Palomo J, Fiandor-Roman AR, Bobolea ID, Sanchez-Pastor S, Pascual CY, Quirce S. Oral challenge with Pasteurized egg white from gallus domesticus. Int Arch Allergy Immunol 2010: 151: 331-5.

28. Escudero C, Sanchez-Garcia S, Rodriguez del Rio P, et al. Dehydrated egg white: an allergen source for improving efficacy and safety in the diagnosis and treatment of egg allergy. Pediatr Allergy Immunol 2013: 24: 263-9.

29. Boyano Martínez T, García-Ara C, Díaz-Pena JM, Muñoz FM, García Sánchez G, Esteban MM. Validity of specific IgE antibodies in children with egg allergy. Clin Exp Allergy 2001: 31: $1464-9$.

30. Alvaro M, García-Paba MB, Giner MT, et al. Tolerance to egg proteins in egg-sensitized infants without previous consumption. Allergy 2014: 69:1350-6.

31. Diéguez MC, Cerecedo I, Muriel A, et al. Utility of diagnostic tests in the follow-up of eggallergic children. Clin Exp Allergy 2009: 39: 1575-84.

32. Benhamou AH, Zamora SA, Eigenmann PA. Correlation between specific immunoglobulin E levels and the severity of reactions in egg allergic patients. Pediatr Allergy Immunol 2008: 19:173-9.

33. Perry TT, Matsui EC, Kay Conover-Walker M, et al. The relationship of allergen-specific IgE levels and oral food challenge outcome. J Allergy Clin Immunol 2004: 114: 144-9.

34. D'Urbano LE, Pellegrino K, Artesani MC, et al. Performance of a component-based allergenmicroarray in the diagnosis of cow's milk and hen's egg allergy. Clin Exp Allergy 2010: 40: 1561-70.

This article is protected by copyright. All rights reserved. 
35. Vazquez-Ortiz M, Pascal M, Jiménez-Feijoo R, et al. Ovalbumin-specific IgE/IgG4 ratio might improve the prediction of cooked and uncooked egg tolerance development in egg-allergic children. Clin Exp Allergy 2014: 44: 579-88.

36. Monti G, Muratore MC, Peltran A, et al. High incidence of adverse reactions to egg challenge on first known exposure in young atopic dermatitis children: predictive value of skin prick test and radioallergosorbent test to egg proteins. Clin Exp Allergy 2002: 32: 1515-9.

37. Tripodi S, Di Rienzo Businco A, Alessandri C, Panetta V, Restani P, Matricardi PM. Predicting the outcome of oral food challenges with hen's egg through skin test end-point titration. Clin Exp Allergy 2009: 39: 1225-33.

38. Sporik R, Hill DJ, Hosking CS. Specificity of allergen skin testing in predicting positive open food challenges to milk, egg and peanut in children. Clin Exp Allergy 2000: 30: 1540-6.

39. Des Roches A, Nguyen M, Paradis L, Primeau MN, Singer S. Tolerance to coke egg in an egg allergic population. Allergy 2006: 61: 900-1.

40. Turner PJ, Kumar K, Fox AT. Skin testing with raw egg does not predict tolerance to baked egg in egg-allergic children. Pediatr Allergy Immunol 2014: 25: 657-61.

41. Bartnikas LM, Sheehan WJ, Larabee KS, Petty C, Schneider LC, Phipatanakul W. Ovomucoid is not superior to egg white testing in predicting tolerance to baked egg. J Allergy Clin Immunol Pract 2013: 1: 354-60.

42. Lieberman JA, Huang FR, Sampson HA, Nowak-Wegrzyn A. Outcomes of 100 consecutive open, baked-egg oral food challenges in the allergy office. J Allergy Clin Immunol 2012: 129: $1682-4$.

43. Lemon Mulé H, Sampson HA, Sicherer S, Shreffler WG, Noone S, Nowak-Wegrzyn A: Immunologic changes in children with egg allergy ingestin heates egg. J Allergy Clin Immunol 2008: 122: 977-83.

This article is protected by copyright. All rights reserved. 
44. Cortot CF, Sheehan WJ, Permaul P, et al. Role of specific IgE and Skin-prick testing in predicting food challenge results to baked egg. Allergy Asthma Proc 2012: 33: 275-81.

45. Tan JW, Campbell DE, Turner PJ, Kakakios A, Wong M, Mehr S, Joshi P. Baked egg food challenges - clinical utility of skin test to baked egg and ovomucoid in children with egg allergy. Clin Exp Allergy 2013: 43: 1189-95.

46. Faraj Z, Kim HL. Skin prick testing with extensively heated milk or egg helps predict the outcome of an oral food challenge: a retrospective analysis. Allergy Asthma \& Clinical Immunology 2012: 8: 5 .

47. Osterballe M, Bindslev-Jensen C. Threshold levels in food challenge and specific IgE in patients with egg allergy: is there a relationship? J Allergy Clin Immunol 2003: 112: 196-201.

48. Celik-Bilgili S, Mehl A, Verstege A, et al. The predictive value of specific immunoglobulin E levels in seum for the outcome of oral food challenges. Clin Exp Allergy 2005: 35: 268-73.

49. Roehr CC, Reibel S, Ziegert M, et al. Atopy patch tests, together with determination of specific IgE levels, reduce the need for oral challenges in children with atopic dermatitis. J Allergy Clin Immunol 2001: 107: 548-53.

50. Ott H, Baron J, M., Heise R, et al. Clinical usefulness of microrray-based IgE detection in children with suspected food allergy. Allergy 2008: 63: 1521-8.

51. Crespo JF, Pascual C, Ferrer A, et al. Egg White-Specific IgE Level as a Tolerance Marker in the Follow Up of Egg Allergy. Allergy Proc 1994: 15: 73-76.

52. Ando H, Movérare R, Kondo Y, et al. Utility of ovomucoid-specific IgE concentrations in predicting symptomatic egg allergy. J Allergy Clin Immunol 2008: 122: 583-8.

53. Sampson H.A. Utility of food-specific $\operatorname{IgE}$ concentrations in predicting symptomatic food allergy. J Allergy Clin Immunol 2001: 107: 891-6.

This article is protected by copyright. All rights reserved. 
54. Benhamou AH, Borres MP,Eigenmann PA. Native and denatured egg white protein IgE tests discriminate hen's egg allergic from egg tolerant children. Pediatr Allergy Immunol 2015: 26: 1217.

55. Min TK, Jeon YH, Yang HJ, Pyun BY. The clinical usefulness of IgE antibodies against egg white and its components in Korean children. Allergy Asthma Immunol Res 2013; 5(3): 138-142.

56. Komata T, Söderström L, Borres MP, Tachimoto H, Ebisawa M. The predictive relationship of food-specific serum IgE concentrations to challenge outcomes for egg and milk varies by patient age. J Allergy Clin Immunol 2007: 119: 1272-4.

57. Haneda Y, Kando N, Yasui M, et al. Ovomucoids IgE is a better marker than egg white-specific IgE to diagnose boiled egg allergy. J Allergy Clin Immunol 2012: 129: 1681-82.

58. Konstantinou GN, Giavi S, Kalobatsou A, et al. Consumption of heat-treated egg by children allergic or sensitized to egg can affect the natural course of egg allergy: Hypothesis generating observations. J Allergy Clin Immunol 2008: 122: 414-5.

59. Marriage DE, Erlewyn-Lajeunesse M, Unsworth DJ, Henderson AJ. Unscrambling egg allergy: the diagnostic value of specific IgE concentrations and skin prick tests for ovomucoid and egg white in the management of children with hen's egg allergy. ISRN Allergy 2012: $627545: 6$ pages.

60. Caubet JC, Bencharitiwong R, Moshier E, Godbold JH, Sampson HA, Nowak-Wegrzyn A. Significance of ovomucoid- and ovalbumin-specific IgE/IgG4 ratios in egg allergy. J Allergy Clin Immunol 2012: 129: 739-47.

61. Joo K, Kato Y. Assessment of allergenic activity of a heat-coagulated ovalbumin after in vivo digestion. Biosci Biotechnol Biochem 2006: 70: 591-7.

62. Cooke SK, Sampson HA. Allergenic properties of ovomucoid in man. J Immunol 1997: 159: 2026-32.

This article is protected by copyright. All rights reserved. 
63. Shriver SK, Yang WW. Thermal and nonthermal methods for food allergen control. Food Eng Rev 2011: 3: 26-43.

64. Hoffman DR. Immunochemical identification of the allergens in egg white. J Allergy Clin Immunol 1983: 71: 481-6.

65. Sterne K. Essential Medical Statistics, 2nd ed. Melbourne, Vic., Australia: Blackwell Science Ltd, 2003.

Table 1 - Studies and suggested cut-offs for raw egg allergy diagnosis using egg white, ovoalbumin and ovomucoid SPTs stratified by the type of allergen used to perform SPTs, design and age $(<2$ years and $\geq 2$ years)

a) Skin Prick Test (commercial extracts)

\begin{tabular}{|c|c|c|c|c|c|c|c|c|c|c|c|c|}
\hline $\begin{array}{l}\text { A } \\
\text { ge }\end{array}$ & $\begin{array}{c}\text { Stud } \\
\mathbf{y}\end{array}$ & $\begin{array}{c}\text { OF } \\
\text { C } \\
\text { Typ } \\
\text { e } \\
\text { (n) }\end{array}$ & $\begin{array}{c}\text { Age } \\
\text { Medi } \\
\text { an } \\
\text { (rang } \\
\text { e) } \\
\text { or } \\
\text { Mean } \\
{[ \pm} \\
\text { SD] }\end{array}$ & $\begin{array}{c}\text { Allerg } \\
y \\
\text { preval } \\
\text { ence } \\
(\%)\end{array}$ & $\begin{array}{c}\text { Egg } \\
\text { admini } \\
\text { stered }\end{array}$ & Design & $\begin{array}{c}\text { Meth } \\
\text { od }\end{array}$ & $\begin{array}{c}\text { Eg } \\
\text { g } \\
\text { wh } \\
\text { ite } \\
\text { cut } \\
- \\
\text { off } \\
\text { (m } \\
\text { m) }\end{array}$ & $\begin{array}{l}\text { Ovoalb } \\
\text { umin } \\
\text { cut off } \\
(\mathrm{mm})\end{array}$ & $\begin{array}{l}\text { Ovom } \\
\text { ucoid } \\
\text { cut off } \\
(\mathrm{mm})\end{array}$ & $\begin{array}{c}\text { Diagno } \\
\text { stics }\end{array}$ & $\begin{array}{l}\text { QUADAS-2 } \\
\text { Domains } 1234 \\
\text { Risk of Bias } 123 \\
\text { Applicability }\end{array}$ \\
\hline $\begin{array}{l}< \\
2 \\
\text { yr }\end{array}$ & $\begin{array}{c}\text { Mon } \\
\text { ti } \\
2002 \\
(36)\end{array}$ & $\begin{array}{l}\text { Ope } \\
\text { n } \\
(107 \\
)\end{array}$ & $\begin{array}{c}5 \text { mos } \\
(1-19 \\
\text { mos })\end{array}$ & 67 & $\begin{array}{l}\text { Raw } \\
\text { egg }\end{array}$ & $\begin{array}{l}\text { Prospe } \\
\text { ctive }\end{array}$ & $\begin{array}{c}100 \% \\
\text { PPV } \\
100 \% \\
\mathrm{Sp} \\
N S\end{array}$ & 5 & ND & ND & $\begin{array}{l}\text { NEO- } \\
\text { Abello }\end{array}$ & \\
\hline & $\begin{array}{l}\text { Peter } \\
\text { s } \\
2013 \\
(16)\end{array}$ & $\begin{array}{c}\text { Ope } \\
\text { n } \\
(650 \\
)\end{array}$ & $\begin{array}{l}12.6 \\
\operatorname{mos} \\
{[ \pm 0.7} \\
\operatorname{mos}]\end{array}$ & 68 & $\begin{array}{c}\text { Raw } \\
\text { egg }\end{array}$ & $\begin{array}{l}\text { Prospe } \\
\text { ctive }\end{array}$ & $\begin{array}{c}95 \% \\
\mathrm{PPV} \\
93 \% \\
\mathrm{Sp} \\
L R\end{array}$ & 4 & ND & ND & $\begin{array}{l}\text { ALK- } \\
\text { Abello }\end{array}$ & \\
\hline $\begin{array}{c}\geq \\
2 \\
\text { yr }\end{array}$ & $\begin{array}{l}\text { Trip } \\
\text { odi } \\
2009 \\
(37)\end{array}$ & $\begin{array}{c}\text { Ope } \\
\text { n } \\
(47)\end{array}$ & $\begin{array}{c}6.2 \\
\mathrm{yrs} \\
{[ \pm 4.2} \\
\mathrm{yrs}]\end{array}$ & 43 & $\begin{array}{l}\text { Raw } \\
\text { egg }\end{array}$ & $\begin{array}{l}\text { Prospe } \\
\text { ctive }\end{array}$ & $\begin{array}{c}100 \% \\
\text { PPV } \\
70 \% \\
\text { Sp } \\
\text { ROC }\end{array}$ & 6 & ND & ND & $\begin{array}{c}\text { Stallerg } \\
\text { enes }\end{array}$ & \\
\hline
\end{tabular}

This article is protected by copyright. All rights reserved. 


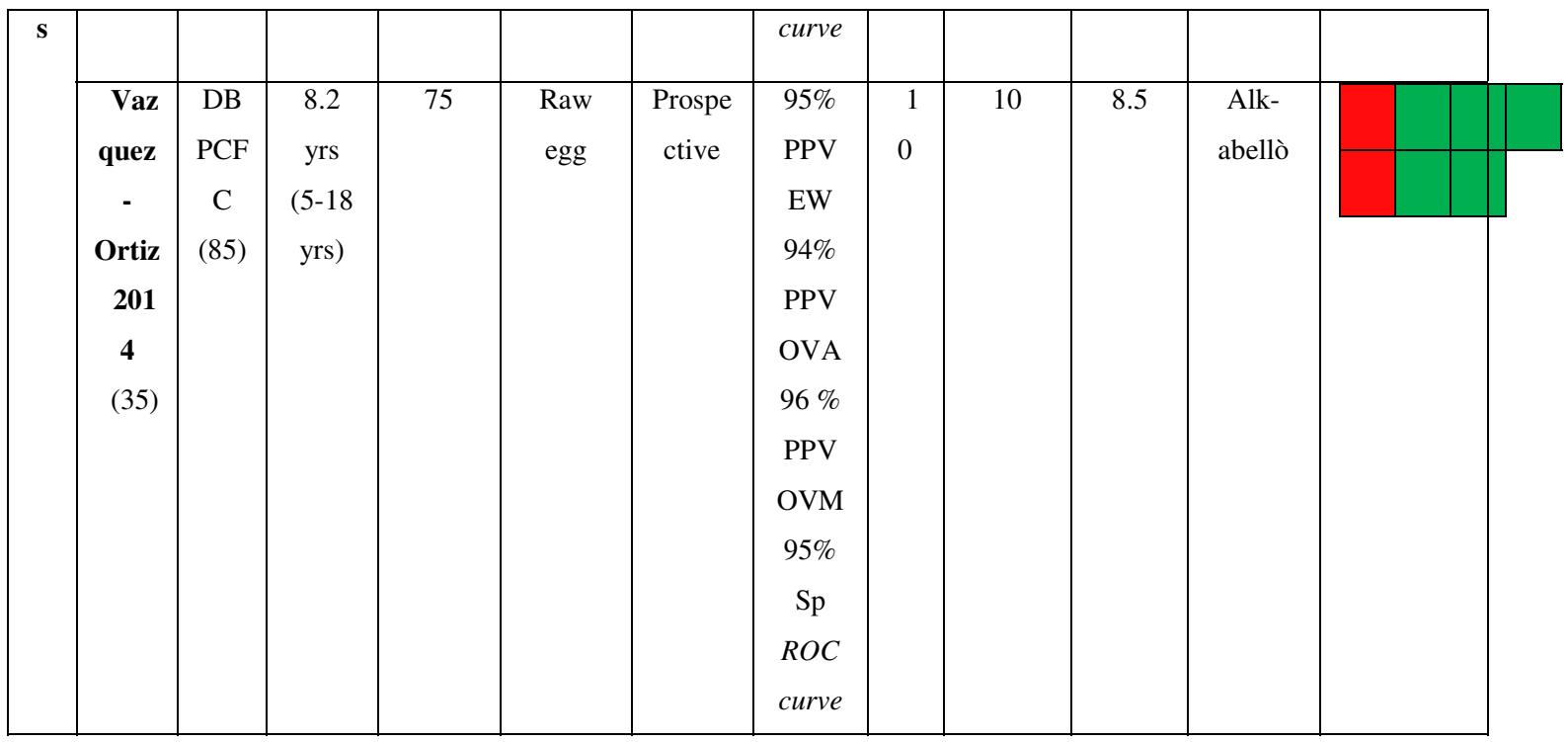

b) Prick by Prick $(\mathrm{PbP})$

\begin{tabular}{|c|c|c|c|c|c|c|c|c|c|c|c|c|}
\hline $\begin{array}{l}\text { A } \\
\text { ge }\end{array}$ & $\begin{array}{c}\text { Stud } \\
\mathbf{y}\end{array}$ & $\begin{array}{c}\text { OF } \\
\text { C } \\
\text { Typ } \\
\text { e } \\
\text { (n) }\end{array}$ & $\begin{array}{c}\text { Age } \\
\text { Medi } \\
\text { an } \\
\text { (rang } \\
\text { e) } \\
\text { or } \\
\text { Mean } \\
{[ \pm} \\
\text { SD] }\end{array}$ & $\begin{array}{c}\text { Allerg } \\
\mathbf{y} \\
\text { preval } \\
\text { ence } \\
(\%)\end{array}$ & $\begin{array}{c}\text { Egg } \\
\text { admini } \\
\text { stered }\end{array}$ & Design & $\begin{array}{l}\text { Met } \\
\text { hod }\end{array}$ & $\begin{array}{c}\text { Pb } \\
\mathbf{P} \\
\text { cut- } \\
\text { off } \\
\text { (m } \\
\text { m) }\end{array}$ & $\begin{array}{c}\text { Ovoalb } \\
\text { umin } \\
\text { cut off } \\
(\mathrm{mm})\end{array}$ & $\begin{array}{l}\text { Ovomu } \\
\text { coid } \\
\text { cut off } \\
(\mathrm{mm})\end{array}$ & $\begin{array}{l}\text { Diagn } \\
\text { ostics }\end{array}$ & $\begin{array}{l}\text { QUADAS-2 } \\
\text { Domains } 1234 \\
\text { Risk of Bias } 123 \\
\text { Applicability }\end{array}$ \\
\hline $\begin{array}{l}\geq \\
2 \\
\text { yr }\end{array}$ & $\begin{array}{c}\text { Verst } \\
\text { ege } \\
2005 \\
(11)\end{array}$ & $\begin{array}{c}\text { DBP } \\
\text { CFC } \\
/ \\
\text { Ope } \\
n \\
(160 \\
)\end{array}$ & $\begin{array}{c}22 \\
\text { mos } \\
(3 \\
\text { mos- } \\
14.5 \\
\text { yrs })\end{array}$ & 63 & $\begin{array}{l}\text { Raw } \\
\text { egg }\end{array}$ & $\begin{array}{l}\text { Retrosp } \\
\text { ective }\end{array}$ & $\begin{array}{c}95 \% \\
\text { PPV } \\
\text { NS } \\
\text { Sp } \\
R L\end{array}$ & 13 & ND & ND & $\begin{array}{c}\text { Fresh } \\
\text { HE } \\
\text { wiske } \\
\mathrm{d} \\
\text { white } \\
\text { and } \\
\text { yolk }\end{array}$ & \\
\hline & $\begin{array}{r}\text { Mehl } \\
2006 \\
(12)\end{array}$ & $\begin{array}{c}\text { DBP } \\
\text { CFC } \\
/ \\
\text { Ope } \\
\text { n } \\
(193 \\
)\end{array}$ & $\begin{array}{c}13 \\
\text { mos } \\
(3 \\
\text { mos- } \\
14 \\
\text { yrs })\end{array}$ & 66 & $\begin{array}{c}\text { Raw } \\
\text { egg }\end{array}$ & $\begin{array}{l}\text { Prospec } \\
\text { tive }\end{array}$ & $\begin{array}{c}95 \% \\
\text { PPV } \\
\text { NS } \\
\text { Sp } \\
R L\end{array}$ & 14 & ND & ND & $\begin{array}{c}\text { Fresh } \\
\text { HE } \\
\text { wiske } \\
\text { d } \\
\text { white } \\
\text { and } \\
\text { yolk }\end{array}$ & \\
\hline
\end{tabular}

PPV: Positive Predictive Value; Sp: Specificity; ROC: Receiver Operating Charateristic (ROC) curve; RL: logistic regression; NS: not specified; ND not determined; EW: egg white, OVA: ovoalbumin; OVM: ovomucoid.

This article is protected by copyright. All rights reserved. 
Table 2 - Study and suggested cut-offs for heated egg allergy diagnosis using egg white, ovoalbumin and ovomucoid SPTs (commercial extracts), stratified by design and age ( $<2$ years and $\geq 2$ years)

\begin{tabular}{|c|c|c|c|c|c|c|c|c|c|c|c|c|}
\hline Age & $\begin{array}{c}\text { Stud } \\
\mathbf{y}\end{array}$ & $\begin{array}{c}\text { OF } \\
\text { C } \\
\text { Typ } \\
\mathbf{e} \\
\text { (n) }\end{array}$ & $\begin{array}{c}\text { Age } \\
\text { Med } \\
\text { ian } \\
\text { (ran } \\
\text { ge) } \\
\text { or } \\
\text { Mea } \\
\text { n } \\
{[ \pm} \\
\text { SD] }\end{array}$ & $\begin{array}{c}\text { Allerg } \\
\mathbf{y} \\
\text { preval } \\
\text { ence } \\
(\%)\end{array}$ & $\begin{array}{c}\text { Egg } \\
\text { administe } \\
\text { red }\end{array}$ & Design & $\begin{array}{c}\text { Metho } \\
\text { d }\end{array}$ & $\begin{array}{c}\text { Egg } \\
\text { white } \\
\text { cut- } \\
\text { off } \\
(\mathrm{mm})\end{array}$ & $\begin{array}{l}\text { Ovoalbu } \\
\text { min } \\
\text { cut off } \\
(\mathrm{mm})\end{array}$ & $\begin{array}{l}\text { Ovom } \\
\text { ucoid } \\
\text { cut off } \\
(\mathbf{m m})\end{array}$ & $\begin{array}{l}\text { Diagnosti } \\
\text { cs }\end{array}$ & $\begin{array}{l}\text { QUADAS } \\
\text { Domains } 1 \text { 2 } \\
\text { Risk of Bias } \\
\text { Applicability }\end{array}$ \\
\hline $\begin{array}{l}<2 \\
\text { yrs }\end{array}$ & $\begin{array}{c}\text { Spori } \\
\mathbf{k} \\
\mathbf{2 0 0 0} \\
(38)\end{array}$ & $\begin{array}{c}\text { Ope } \\
\text { n } \\
(39)\end{array}$ & $\begin{array}{l}<2 \\
\text { yrs }\end{array}$ & 74 & $\begin{array}{l}\text { Lightly } \\
\text { heated } \\
\text { egg white } \\
\text { (approx } 2 \\
\text { min) }\end{array}$ & $\begin{array}{l}\text { Prospe } \\
\text { ctive }\end{array}$ & $\begin{array}{c}\mathrm{NS} \\
\mathrm{PPV} \\
100 \% \\
\mathrm{Sp} \\
\text { ROC } \\
\text { curve }\end{array}$ & 5 & ND & ND & $\begin{array}{c}\text { Dome } \\
\text { Hollister } \\
\text { Stier }\end{array}$ & \\
\hline & $\begin{array}{c}\text { Spori } \\
\mathbf{k} \\
\mathbf{2 0 0 0} \\
(38)\end{array}$ & $\begin{array}{c}\text { Ope } \\
\text { n } \\
(82)\end{array}$ & $\begin{array}{l}>2 \\
\text { yrs } \\
(2- \\
12.8 \\
\text { yrs })\end{array}$ & 78 & $\begin{array}{l}\text { Lightly } \\
\text { heated } \\
\text { egg white } \\
\text { (approx } 2 \\
\text { min) }\end{array}$ & $\begin{array}{l}\text { Prospe } \\
\text { ctive }\end{array}$ & $\begin{array}{c}\mathrm{NS} \\
\mathrm{PPV} \\
100 \% \\
\mathrm{Sp} \\
\text { ROC } \\
\text { curve }\end{array}$ & 7 & ND & ND & $\begin{array}{c}\text { Dome } \\
\text { Hollister } \\
\text { Stier }\end{array}$ & \\
\hline $\begin{array}{l}\geq 2 \\
\text { yrs }\end{array}$ & $\begin{array}{r}\text { Vaz } \\
\text { quez- } \\
\text { Ortiz } \\
\mathbf{2 0 1} \\
\mathbf{4} \\
(35)\end{array}$ & $\begin{array}{l}\text { DB } \\
\text { PCF } \\
\text { C } \\
(85)\end{array}$ & $\begin{array}{c}8.2 \\
\text { yrs } \\
(5- \\
18 \\
\text { yrs })\end{array}$ & 59 & $\begin{array}{c}\text { One egg } \\
\text { boiled for } \\
10 \text { min at } \\
90^{\circ}\end{array}$ & $\begin{array}{l}\text { Prospe } \\
\text { ctive }\end{array}$ & $\begin{array}{c}82 \% \\
\text { PPV } \\
\text { EW } \\
87 \% \\
\text { PPV } \\
\text { OVA } \\
75 \% \\
\text { PPV } \\
\text { OVM } \\
95 \% \\
\text { Sp } \\
\text { ROC } \\
\text { curve }\end{array}$ & 11 & 10.5 & 13 & $\begin{array}{l}\text { Alk- } \\
\text { Abellò }\end{array}$ & \\
\hline
\end{tabular}

PPV: Positive Predictive Value; Sp: Specificity; ROC: Receiver Operating Charateristic (ROC) curve; RL: logistic regression; NS: not specified; ND: not determined; EW: egg white, OVA: ovoalbumin; OVM: ovomucoid

This article is protected by copyright. All rights reserved. 
Table 3 - Studies and suggested cut-offs for baked egg allergy diagnosis using egg white, ovoalbumin and ovomucoid SPTs, stratified by the type of allergen used to perform SPTs, design and age $(<2$ years and $\geq 2$ years)

a) Skin Prick Test (commercial extracts)

\begin{tabular}{|c|c|c|c|c|c|c|c|c|c|c|c|c|}
\hline $\begin{array}{l}\mathbf{A} \\
\text { g } \\
\text { e }\end{array}$ & Study & $\begin{array}{l}\text { OF } \\
\text { C } \\
\text { Ty } \\
\text { pe } \\
\text { (n) }\end{array}$ & $\begin{array}{c}\text { Age } \\
\text { Medi } \\
\text { an } \\
\text { (rang } \\
\text { e) } \\
\text { or } \\
\text { Mean } \\
{[ \pm} \\
\text { SD] }\end{array}$ & $\begin{array}{c}\text { Allerg } \\
\mathbf{y} \\
\text { preval } \\
\text { ence } \\
(\%)\end{array}$ & $\begin{array}{c}\text { Egg } \\
\begin{array}{c}\text { administer } \\
\text { ed }\end{array}\end{array}$ & Design & $\begin{array}{c}\text { Meth } \\
\text { od }\end{array}$ & $\begin{array}{l}\text { Egg } \\
\text { whi } \\
\text { te } \\
\text { cut- } \\
\text { off } \\
\text { (m } \\
\text { m) }\end{array}$ & $\begin{array}{l}\text { Ovoalbu } \\
\text { min } \\
\text { Cut off } \\
(\mathrm{mm})\end{array}$ & $\begin{array}{c}\text { Ovom } \\
\text { ucoid } \\
\text { cut off } \\
(\mathrm{mm})\end{array}$ & $\begin{array}{c}\text { Diagnos } \\
\text { tics }\end{array}$ & $\begin{array}{l}\text { QUADAS- } \\
2 \\
\text { Domains } \\
1234 \text { Risk } \\
\text { of Bias } \\
123 \\
\text { Applicability }\end{array}$ \\
\hline $\begin{array}{l}< \\
2 \\
y \\
\text { rs }\end{array}$ & $\begin{array}{c}\text { Peters } \\
\mathbf{2 0 1 3} \\
(16)\end{array}$ & $\begin{array}{l}\text { Op } \\
\text { en } \\
(18 \\
5)\end{array}$ & $\begin{array}{c}12.6 \\
\text { mos } \\
{[ \pm 0.7} \\
\text { mos }]\end{array}$ & NS & $\begin{array}{l}\text { OFC with a } \\
\text { muffin }\end{array}$ & $\begin{array}{l}\text { Prospecti } \\
\text { ve }\end{array}$ & $\begin{array}{c}82 \% \\
\text { PPV } \\
\text { NS } \\
\text { Sp } \\
R L\end{array}$ & 11 & ND & ND & $\begin{array}{l}\text { ALK- } \\
\text { Abellò }\end{array}$ & \\
\hline \multirow{3}{*}{$\begin{array}{l}\geq \\
2 \\
\text { y } \\
\text { rs }\end{array}$} & $\begin{array}{c}\text { Des } \\
\text { Roches } \\
\mathbf{2 0 0 6} \\
(39)\end{array}$ & $\begin{array}{l}\text { Op } \\
\text { en } \\
(60 \\
)\end{array}$ & $\begin{array}{l}>5 \\
\text { yrs }\end{array}$ & 27 & $\begin{array}{c}\text { Cake } \\
\text { (unspecified } \\
\text { amount of } \\
\text { egg) }\end{array}$ & $\begin{array}{c}\text { Prospecti } \\
\text { ve }\end{array}$ & $N S$ & ND & ND & ND & ND & \\
\hline & $\begin{array}{c}\text { Turner } \\
\mathbf{2 0 1 4} \\
(40)\end{array}$ & $\begin{array}{l}\text { Op } \\
\text { en } \\
(18 \\
6)\end{array}$ & $\begin{array}{c}5.3 \\
\text { yrs } \\
(3.3- \\
9.8 \\
\text { yrs })\end{array}$ & 34 & $\begin{array}{c}\text { A muffin } \\
\text { containing } \\
3 \mathrm{~g} \text { of an egg } \\
\text { and baked } \\
\text { for } 20^{\prime} \text { at } \\
180^{\circ} \mathrm{C}\end{array}$ & $\begin{array}{c}\text { Retrospec } \\
\text { tive }\end{array}$ & $\begin{array}{c}\text { NS } \\
\text { PPV } \\
98 \% \\
\text { Sp } \\
\text { ROC } \\
\text { curve }\end{array}$ & 12 & ND & ND & $\begin{array}{c}\text { Stallerge } \\
\text { nes }\end{array}$ & \\
\hline & $\begin{array}{c}\text { Bartnik } \\
\text { as } \\
\mathbf{2 0 1 3} \\
(41)\end{array}$ & $\begin{array}{l}\text { Op } \\
\text { en } \\
(16 \\
9)\end{array}$ & $\begin{array}{c}5.5 \\
\text { yrs } \\
(0.8- \\
17 \\
\text { yrs })\end{array}$ & 16 & $\begin{array}{l}\text { OFC with } \\
\text { muffin or } \\
\text { cake }(1 / 3 \text { of } \\
\text { egg) }\end{array}$ & $\begin{array}{l}\text { Retrospec } \\
\text { tive }\end{array}$ & $\begin{array}{c}90 \% \mathrm{P} \\
\mathrm{PV} \\
\mathrm{NS} \\
\mathrm{Sp} \\
\text { ROC } \\
\text { curve }\end{array}$ & 25 & ND & ND & $\begin{array}{c}\text { Greer } \\
\text { Laborato } \\
\text { ries }\end{array}$ & \\
\hline
\end{tabular}

This article is protected by copyright. All rights reserved. 


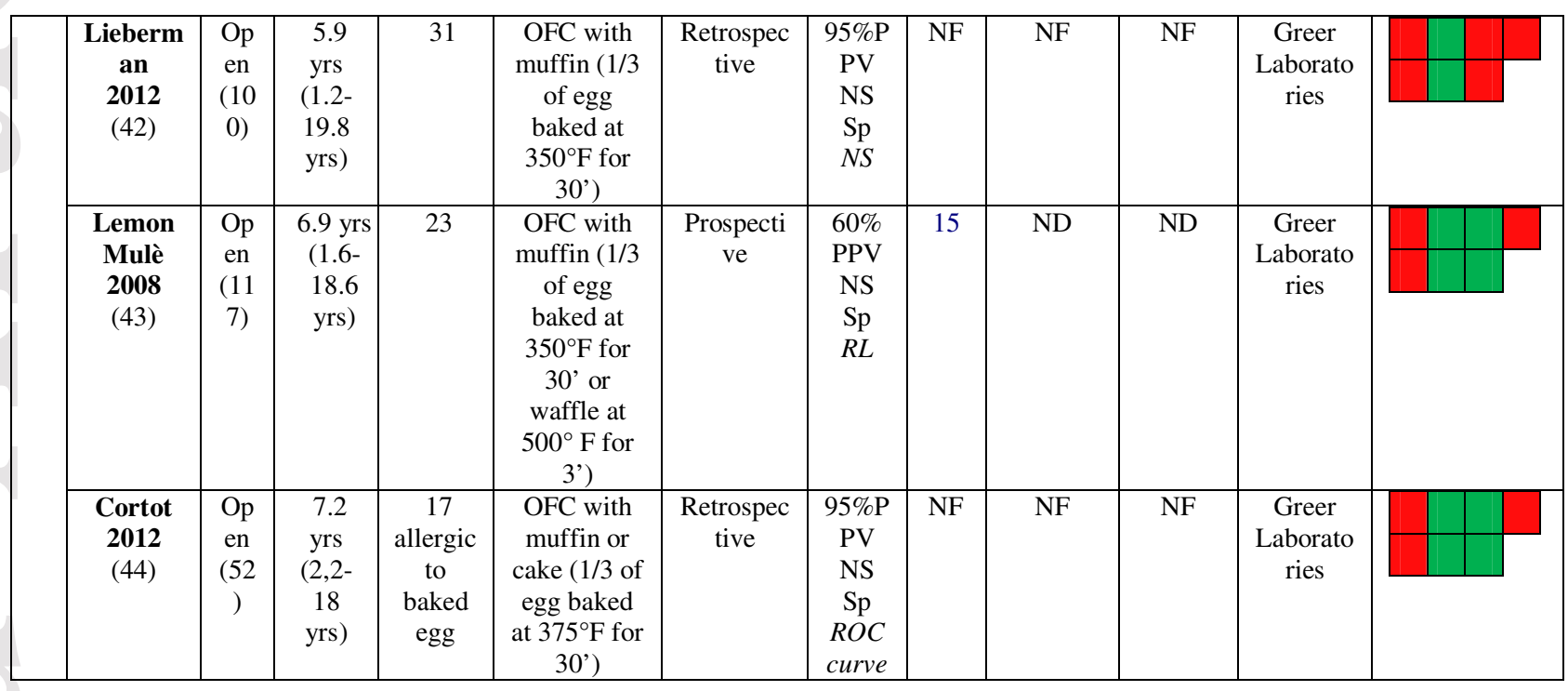

This article is protected by copyright. All rights reserved. 
b) Prick by Prick $(\mathrm{PbP})$

\begin{tabular}{|c|c|c|c|c|c|c|c|c|c|c|c|c|}
\hline Age & Study & $\begin{array}{c}\text { OFC } \\
\text { Type } \\
\text { (n) }\end{array}$ & $\begin{array}{c}\text { Age } \\
\text { Median } \\
\text { (range) } \\
\text { or } \\
\text { Mean } \\
{[ \pm \text { SD }]} \\
\end{array}$ & $\begin{array}{c}\text { Allergy } \\
\text { prevalence } \\
(\%)\end{array}$ & $\begin{array}{c}\text { Egg } \\
\text { administered }\end{array}$ & Design & Method & $\begin{array}{l}\text { PbP } \\
\text { cut-off } \\
(\mathbf{m m})\end{array}$ & $\begin{array}{l}\text { Ovoalbumin } \\
\text { Cut off } \\
(\mathbf{m m})\end{array}$ & $\begin{array}{l}\text { Ovomucoid } \\
\text { cut off } \\
\text { (mm) }\end{array}$ & Diagnostics & $\begin{array}{l}\text { QUADAS-2 } \\
\text { Domains } 1234 \\
\text { Risk of Bias } 123 \\
\text { Applicability }\end{array}$ \\
\hline \multirow{3}{*}{$\begin{array}{l}\geq 2 \\
\text { yrs }\end{array}$} & $\begin{array}{l}\text { Tan } \\
2013 \\
(45)\end{array}$ & $\begin{array}{l}\text { Open } \\
(143)\end{array}$ & $\begin{array}{c}3.8 \text { yrs } \\
(1.8-6.7 \\
\text { yrs })\end{array}$ & 37 & $\begin{array}{c}\text { OFC with } \\
\text { muffin }(1 / 6 \text { of } \\
\text { egg baked ad } \\
180^{\circ} \mathrm{C} \text { for } \\
\left.20^{\prime}\right)\end{array}$ & Prospective & $\begin{array}{c}\text { 100\%PPV } \\
\text { NS Sp } \\
\text { ROC } \\
\text { curve }\end{array}$ & ND & ND & 11 & $\begin{array}{l}\text { PbP with a } \\
\text { muffin } \\
\text { containing } \\
\text { baked egg } \\
\text { (Commercial } \\
\text { extract ALK } \\
\text { Abello Spain) }\end{array}$ & \\
\hline & $\begin{array}{l}\text { Faraj } \\
\text { 2012 } \\
(46)\end{array}$ & $\begin{array}{l}\text { Open } \\
(40)\end{array}$ & $\begin{array}{c}3.5 \mathrm{yrs} \\
(1.25-13 \\
\mathrm{yrs})\end{array}$ & 7 & $\begin{array}{c}\text { OFC with } \\
\text { muffin }(1 / 3 \text { of } \\
\text { egg baked at } \\
\left.350^{\circ} \mathrm{F} \text { for } 30^{\prime}\right)\end{array}$ & Retrospective & $N S$ & ND & ND & ND & $\begin{array}{l}\text { PbP with a } \\
\text { muffin } \\
\text { containing } \\
\text { baked egg }\end{array}$ & \\
\hline & $\begin{array}{l}\text { Turner } \\
\mathbf{2 0 1 4} \\
(40)\end{array}$ & $\begin{array}{l}\text { Open } \\
(186)\end{array}$ & $\begin{array}{c}5.3 \text { yrs } \\
(3.3-9.8 \\
\text { yrs })\end{array}$ & 34 & $\begin{array}{c}\text { A muffin } \\
\text { containing } 3 \mathrm{~g} \\
\text { of an egg and } \\
\text { baked for } 20^{\prime} \\
\text { at } 180^{\circ}\end{array}$ & Retrospective & $\begin{array}{l}\text { NS PPV } \\
\text { 95\% } \mathrm{Sp} \\
\text { ROC curve }\end{array}$ & 20 & ND & ND & $\begin{array}{l}\mathrm{PbP} \text { with raw } \\
\text { egg }\end{array}$ & \\
\hline
\end{tabular}

PPV: Positive Predictive Value; Sp: Specificity, ROC: Receiver Operating Charateristic (ROC) curve; RL: logistic regression; NS: not specified; ND: not determined; NF: not found EW: egg white, OVA: ovoalbumin; OVM: ovomucoid

This article is protected by copyright. All rights reserved. 
Table 4 - Studies and proposed cut-offs for raw egg allergy diagnosis with specific IgEs for egg white, ovoalbumin and ovomucoid listed according to study design and patients' age ( $<2$ years and $\geq 2$ years)

\begin{tabular}{|c|c|c|c|c|c|c|c|c|c|c|c|c|}
\hline Age & Study & $\begin{array}{c}\text { OFC } \\
\text { Type } \\
(\mathbf{n})\end{array}$ & $\begin{array}{c}\text { Age } \\
\text { Median } \\
\text { (range) } \\
\text { or } \\
\text { Mean } \\
{[ \pm \text { SD }]}\end{array}$ & $\begin{array}{c}\text { Allergy } \\
\text { prevalence } \\
(\%)\end{array}$ & $\begin{array}{c}\text { Egg } \\
\text { administered }\end{array}$ & Design & Method & $\begin{array}{c}\text { Egg } \\
\text { white } \\
\text { cut-off } \\
\left(\mathbf{k U}_{\mathrm{A}} / \mathrm{L}\right)\end{array}$ & $\begin{array}{c}\text { Ovoalbumin } \\
\text { Cut off } \\
(\mathbf{m m})\end{array}$ & $\begin{array}{c}\text { Ovomucoi } \\
\text { d cut off } \\
(\mathbf{m m})\end{array}$ & Diagnostics & $\begin{array}{l}\text { QUADAS-2 } \\
\text { Domains } 1234 \\
\text { Risk of Bias } 123 \\
\text { Applicability }\end{array}$ \\
\hline & $\begin{array}{c}\text { Monti } \\
\mathbf{2 0 0 2} \\
(36)\end{array}$ & $\begin{array}{l}\text { Open } \\
(107)\end{array}$ & $\begin{array}{c}5 \text { mos } \\
(1-19 \\
\text { mos })\end{array}$ & 67 & Raw egg & Prospective & $\begin{array}{c}\text { NS PPV } \\
100 \% \text { Sp } \\
N S\end{array}$ & $>99$ & ND & $\mathrm{ND}$ & CAP system & \\
\hline $\begin{array}{l}<2 \\
\text { yrs }\end{array}$ & $\begin{array}{l}\text { Peters } \\
2013 \\
(16)\end{array}$ & $\begin{array}{l}\text { Open } \\
(652)\end{array}$ & $\begin{array}{c}12.6 \mathrm{mos} \\
\\
{[ \pm 0.7} \\
\mathrm{mos}]\end{array}$ & 68 & $\begin{array}{c}\text { Raw egg } \\
\text { white }\end{array}$ & Prospective & $\begin{array}{c}95 \% \mathrm{PPV} \\
98 \% \mathrm{Sp} \\
L R\end{array}$ & 1.7 & ND & ND & CAP system & \\
\hline & $\begin{array}{c}\text { Osterballe } \\
\mathbf{2 0 0 3} \\
(47)\end{array}$ & $\begin{array}{l}\text { Open } \\
\text { (28) }\end{array}$ & $\begin{array}{c}1.1 \mathrm{yrs} \\
(0.5-2 \\
\mathrm{yrs})\end{array}$ & $(64)^{*}$ & Raw egg & Retrospective & $\begin{array}{c}100 \% \mathrm{PPV} \\
100 \% \mathrm{Sp} \\
\text { ROC curve }\end{array}$ & 1.5 & ND & ND & $\begin{array}{l}\text { CAP system } \\
\text { and Magic } \\
\text { Lite (Alk- } \\
\text { Abellò) }\end{array}$ & \\
\hline
\end{tabular}

This article is protected by copyright. All rights reserved. 


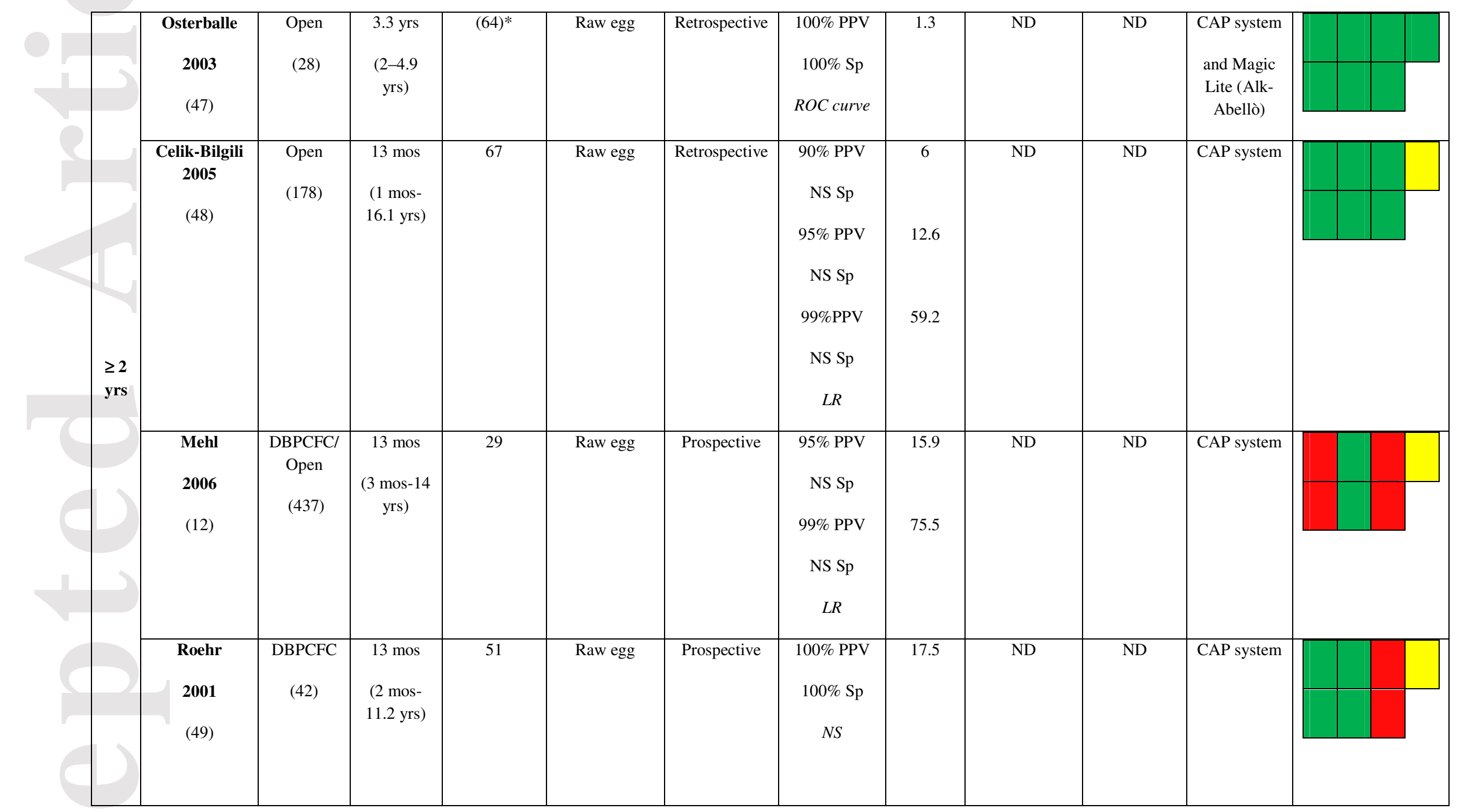

This article is protected by copyright. All rights reserved. 


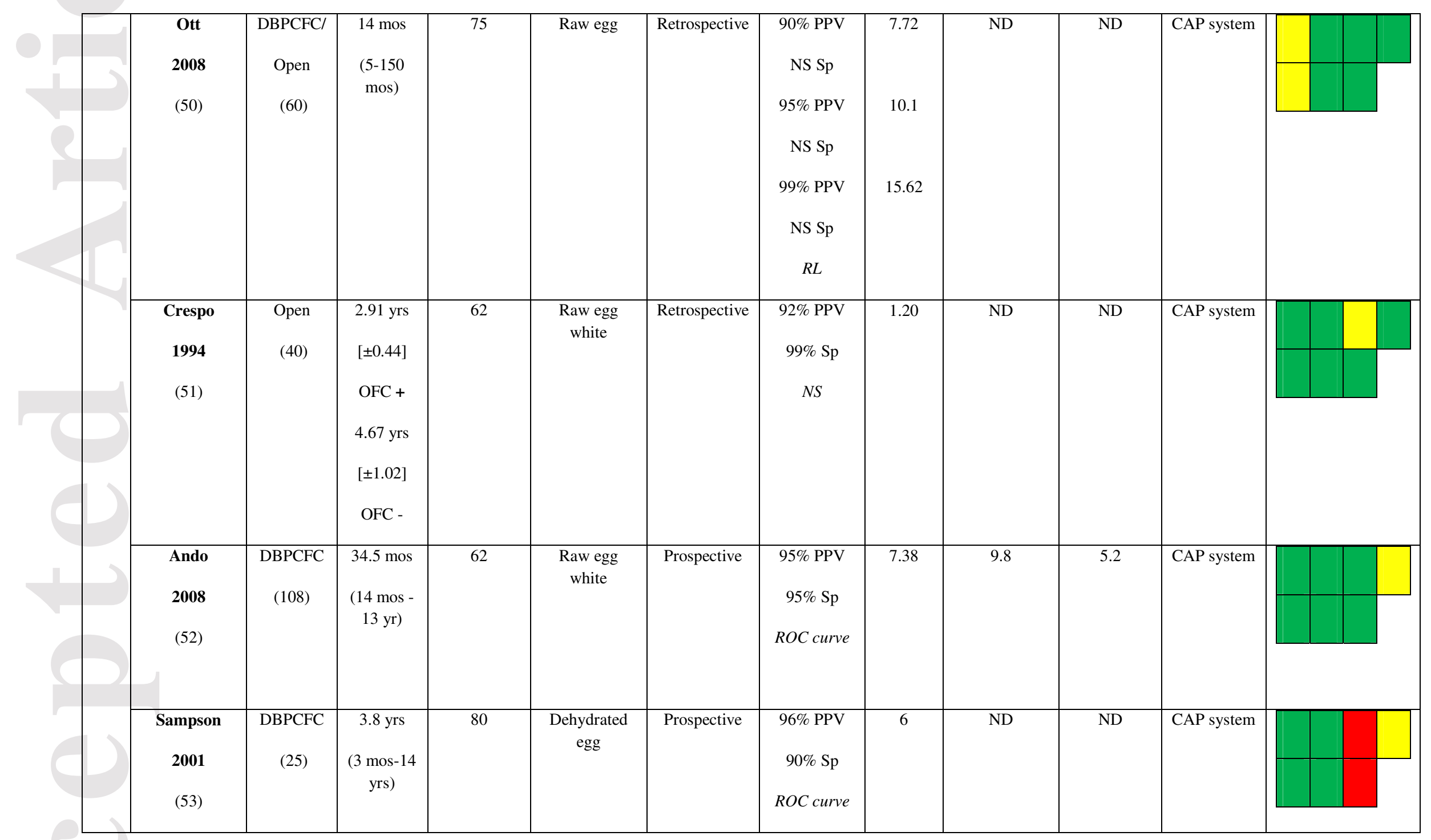

This article is protected by copyright. All rights reserved. 


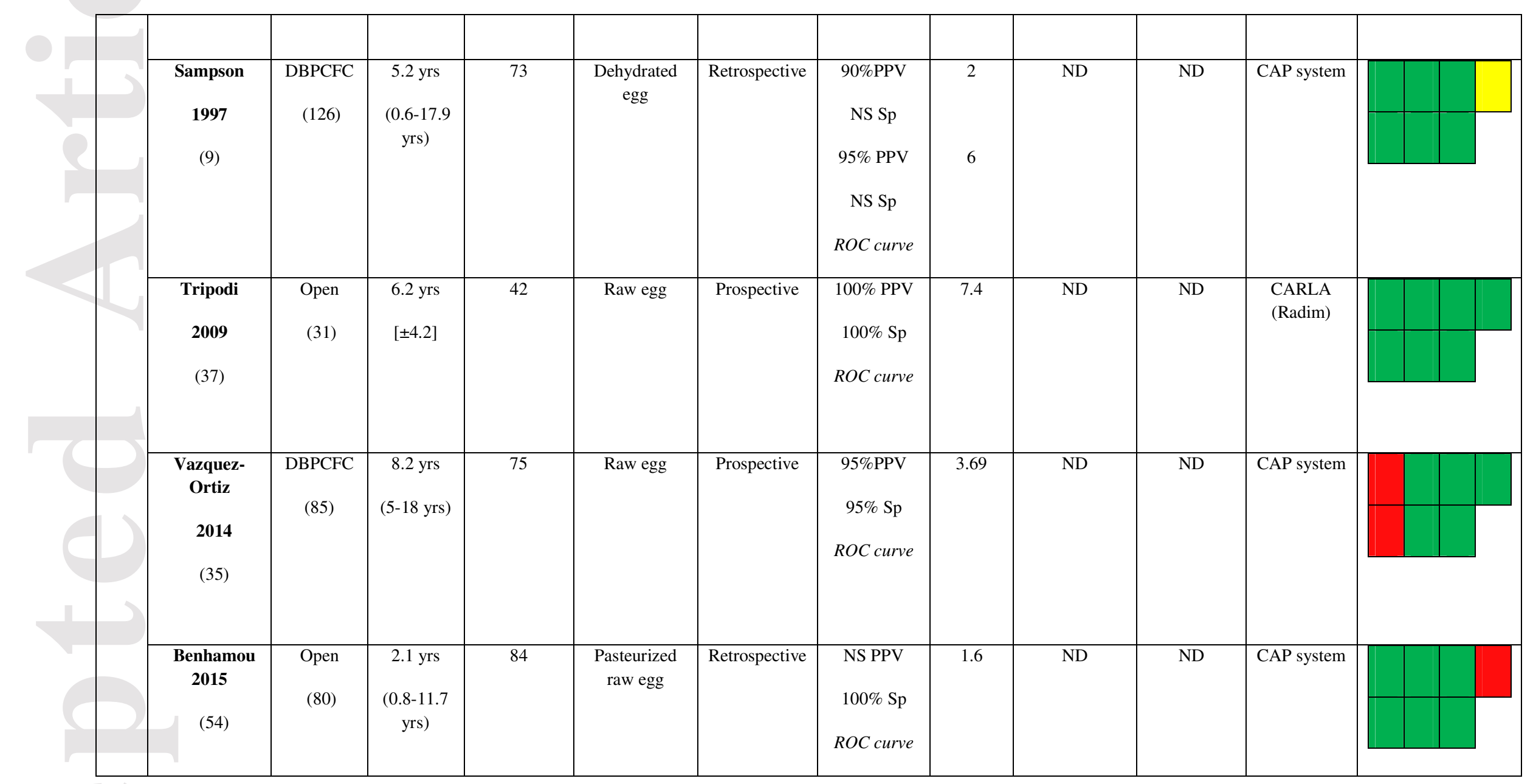

* Overall prevalence of allergy in the two age groups; PPV: Positive Predictive Value; Sp: Specificity, ROC: Receiver Operating Charateristic (ROC) curve; RL: logistic regression; NS: not specified; ND: not determined; EW: egg white, OVA: ovoalbumin; OVM: ovomucoid.

This article is protected by copyright. All rights reserved. 
Table 5 - Studies and proposed cut-offs for heated egg allergy diagnosis with specific IgEs for egg white, ovoalbumin and ovomucoid, listed according to study design and patients' age ( $<2$ years and $\geq 2$ years)

\begin{tabular}{|c|c|c|c|c|c|c|c|c|c|c|c|c|}
\hline 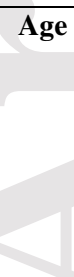 & Study & $\begin{array}{l}\text { OFC } \\
\text { Type } \\
\text { (n) }\end{array}$ & $\begin{array}{c}\text { Age } \\
\text { Median } \\
\text { (range) }\end{array}$ & $\begin{array}{c}\text { Allergy } \\
\text { prevalence } \\
(\%)\end{array}$ & $\begin{array}{c}\text { Egg } \\
\text { administered }\end{array}$ & Design & Method & $\begin{array}{c}\text { Egg white } \\
\text { Cut-off } \\
\left(\mathbf{k U}_{\mathrm{A}} / \mathrm{L}\right)\end{array}$ & $\begin{array}{c}\text { Ovoalbumin } \\
\text { Cut-off } \\
\left(\mathbf{k U}_{\mathrm{A}} / \mathrm{L}\right)\end{array}$ & $\begin{array}{c}\text { Ovomucoid } \\
\text { Cut-off } \\
\left(\mathbf{k U}_{\mathrm{A}} / \mathbf{L}\right)\end{array}$ & Diagnostics & $\begin{array}{l}\text { QUADAS-2 } \\
\text { Domains } 1234 \\
\text { Risk of Bias } 123 \\
\text { Applicability }\end{array}$ \\
\hline & $\begin{array}{l}\text { Min } \\
2013 \\
(55)\end{array}$ & $\begin{array}{l}\text { Open } \\
(41)\end{array}$ & $\begin{array}{c}16 \text { mos } \\
(3-23 \\
\text { mos })\end{array}$ & 61 & $\begin{array}{l}\text { Egg white } \\
\text { boiled for } 15 \\
\text { min }\end{array}$ & Prospective & $\begin{array}{c}71 \% P P V \\
62 \% S p \\
N S\end{array}$ & $\geq 2$ & ND & ND & CAP system & \\
\hline $\begin{array}{l}<2 \\
\text { yrs }\end{array}$ & $\begin{array}{c}\text { Haneda } \\
2012 \\
(57)\end{array}$ & $\begin{array}{l}\text { Open } \\
(100)\end{array}$ & $\begin{array}{c}17 \mathrm{mos} \\
(12-23 \\
\text { mos })\end{array}$ & 33 & $\begin{array}{l}\text { Egg boiled for } \\
>20 \mathrm{~min}(1 / 2 \\
\text { egg) }\end{array}$ & Retrospective & $\begin{array}{c}95 \% \mathrm{PPV} \\
\text { NS Sp } \\
L R\end{array}$ & 61.8 & ND & 26.6 & CAP system & \\
\hline & $\begin{array}{c}\text { Komata } \\
2007 \\
(56)\end{array}$ & $\begin{array}{l}\text { Open } \\
(764)^{\circ}\end{array}$ & $<2 \mathrm{yrs}$ & (49) * & Heated egg & Retrospective & $\begin{array}{c}95 \% \mathrm{PPV} \\
48 \% \mathrm{Sp} \\
\text { ROC curve }\end{array}$ & $\begin{array}{c}13(<1 \mathrm{yr}) \\
23(1-2 \mathrm{yrs})\end{array}$ & ND & $\mathrm{ND}$ & CAP system & \\
\hline$\geq 2$ & $\begin{array}{c}\text { Komata } \\
2007 \\
(56)\end{array}$ & $\begin{array}{l}\text { Open } \\
(764)^{\circ}\end{array}$ & $\begin{array}{c}15 \mathrm{mos} \\
(0.2-14.6 \\
\mathrm{yrs})\end{array}$ & (49) * & Heated egg & Retrospective & $\begin{array}{c}95 \% \mathrm{PPV} \\
48 \% \mathrm{Sp} \\
\text { ROC curve }\end{array}$ & 30 (>2 yrs) & ND & ND & CAP system & \\
\hline
\end{tabular}

This article is protected by copyright. All rights reserved. 


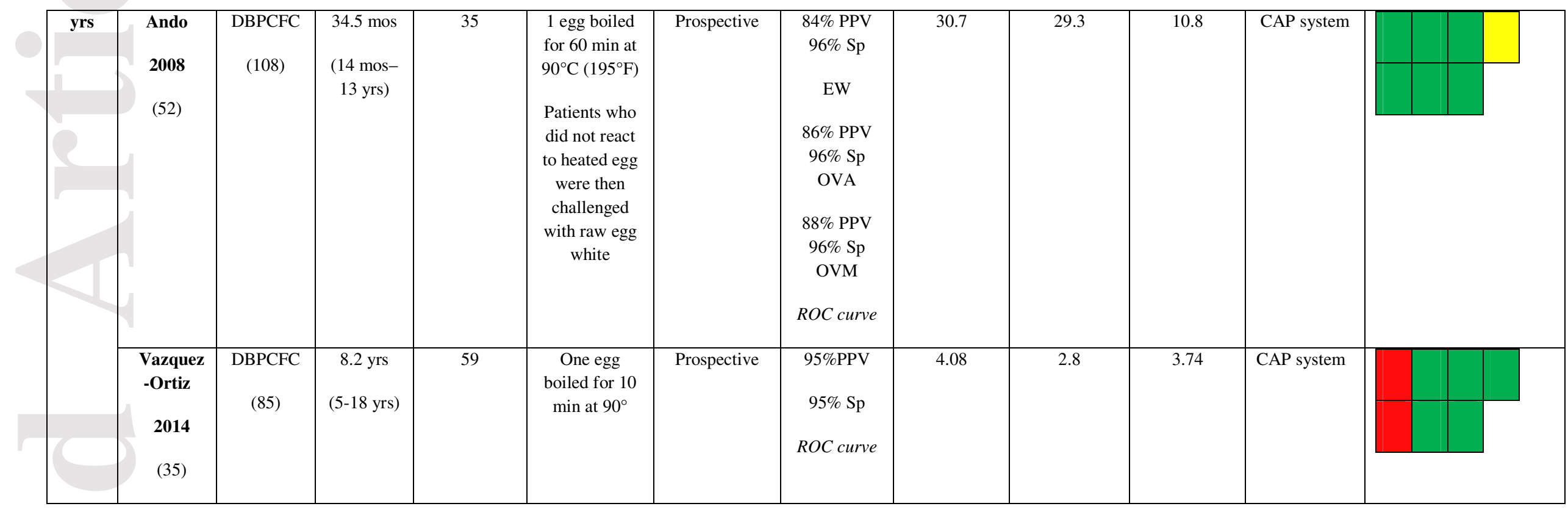

${ }^{\circ}$ Overall number of allergy in the two age groups; * Overall prevalence of allergy in the two age groups; PPV: Positive Predictive Value; Sp: Specificity, ROC: Receiver Operating Charateristic (ROC) curve; RL: logistic regression; NS: not specified; ND: not determined; EW: egg white, OVA: ovoalbumin; OVM: ovomucoid

This article is protected by copyright. All rights reserved. 
Table 6 - Studies and proposed cut-offs for extensively heated (baked) egg allergy diagnosis with specific IgEs for egg white, ovoalbumin and ovomucoid, listed according to the increasing age of the population

\begin{tabular}{|c|c|c|c|c|c|c|c|c|c|c|c|c|}
\hline Age & Study & $\begin{array}{l}\text { OFC } \\
\text { Type } \\
\text { (n) }\end{array}$ & $\begin{array}{c}\text { Age } \\
\text { Median } \\
\text { (range) } \\
\text { or } \\
\text { Mean } \\
{[ \pm \text { SD }]}\end{array}$ & $\begin{array}{c}\begin{array}{c}\text { Allergy } \\
\text { prevalence }\end{array} \\
(\%)\end{array}$ & Egg administered & Design & Method & $\begin{array}{l}\text { Egg white } \\
\text { Cut-off } \\
\left(\mathrm{kU}_{\mathrm{A}} / \mathrm{L}\right)\end{array}$ & $\begin{array}{c}\text { Ovoalbumin } \\
\text { Cut-off } \\
\left(\mathbf{k U}_{\mathrm{A}} / \mathrm{L}\right)\end{array}$ & $\begin{array}{c}\text { Ovomucoid } \\
\text { Cut-off } \\
\left(\mathrm{kU}_{\mathrm{A}} / \mathrm{L}\right)\end{array}$ & Diagnostics & $\begin{array}{l}\text { QUADAS-2 } \\
\text { Domains } 1234 \\
\text { Risk of Bias } 123 \\
\text { Applicability }\end{array}$ \\
\hline & $\begin{array}{c}\text { Kostantinou } \\
\begin{array}{c}\mathbf{2 0 0 8} \\
(58)\end{array}\end{array}$ & $\begin{array}{l}\text { Open } \\
\text { (94) }\end{array}$ & $\begin{array}{c}2.5 \mathrm{mos} \\
(12-48 \\
\mathrm{mos})\end{array}$ & $\begin{array}{c}7 \\
\text { baked egg } \\
\text { allergy } \\
5 \\
\\
\text { raw egg } \\
\text { allergy }\end{array}$ & $\begin{array}{l}\text { A cake containing } 1 \\
\text { egg (not specified } \\
\text { time and } \\
\text { temperature used) }\end{array}$ & Retrospective & $\begin{array}{c}95 \% \text { PPV } \\
\text { Sp NS } \\
N S\end{array}$ & 6 & ND & ND & CAP system & \\
\hline $\begin{array}{l}\geq 2 \\
\text { yrs }\end{array}$ & $\begin{array}{c}\text { Marriage } \\
2012 \\
(59)\end{array}$ & $\begin{array}{l}\text { NS } \\
\text { (47) }\end{array}$ & $\begin{array}{c}4.6 \mathrm{yrs} \\
(2-16 \\
\mathrm{yrs})\end{array}$ & 51 & $\begin{array}{l}\text { Extensively heated } \\
\text { egg (not specified } \\
\text { time and } \\
\text { temperature used) }\end{array}$ & Prospective & $\begin{array}{c}95 \% \text { PPV } \\
\text { Sp 70\% EW } \\
\text { Sp 78\% OVM } \\
\text { ROC curve }\end{array}$ & 10 & ND & 6 & CAP system & \\
\hline 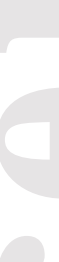 & $\begin{array}{c}\text { Bartnikas } \\
2013 \\
(41)\end{array}$ & $\begin{array}{l}\text { Open } \\
\text { (169) }\end{array}$ & $\begin{array}{c}5.5 \mathrm{yrs} \\
(0.84- \\
17.07 \\
\mathrm{yrs})\end{array}$ & $\begin{array}{c}16 \\
\text { baked egg } \\
\text { allergy }\end{array}$ & $\begin{array}{c}\text { A muffin or } \\
\text { cupcake containing } \\
1 / 3 \text { of an egg and } \\
\text { baked for } 30^{\prime} \text { at } \\
350^{\circ} \mathrm{F}\end{array}$ & Retrospective & $\begin{array}{c}59 \% \text { PPV EW } \\
42 \% \text { PPV OVM } \\
95 \% \mathrm{Sp} \\
\text { ROC curve }\end{array}$ & 9.65 & ND & 3.38 & CAP system & \\
\hline
\end{tabular}

This article is protected by copyright. All rights reserved. 


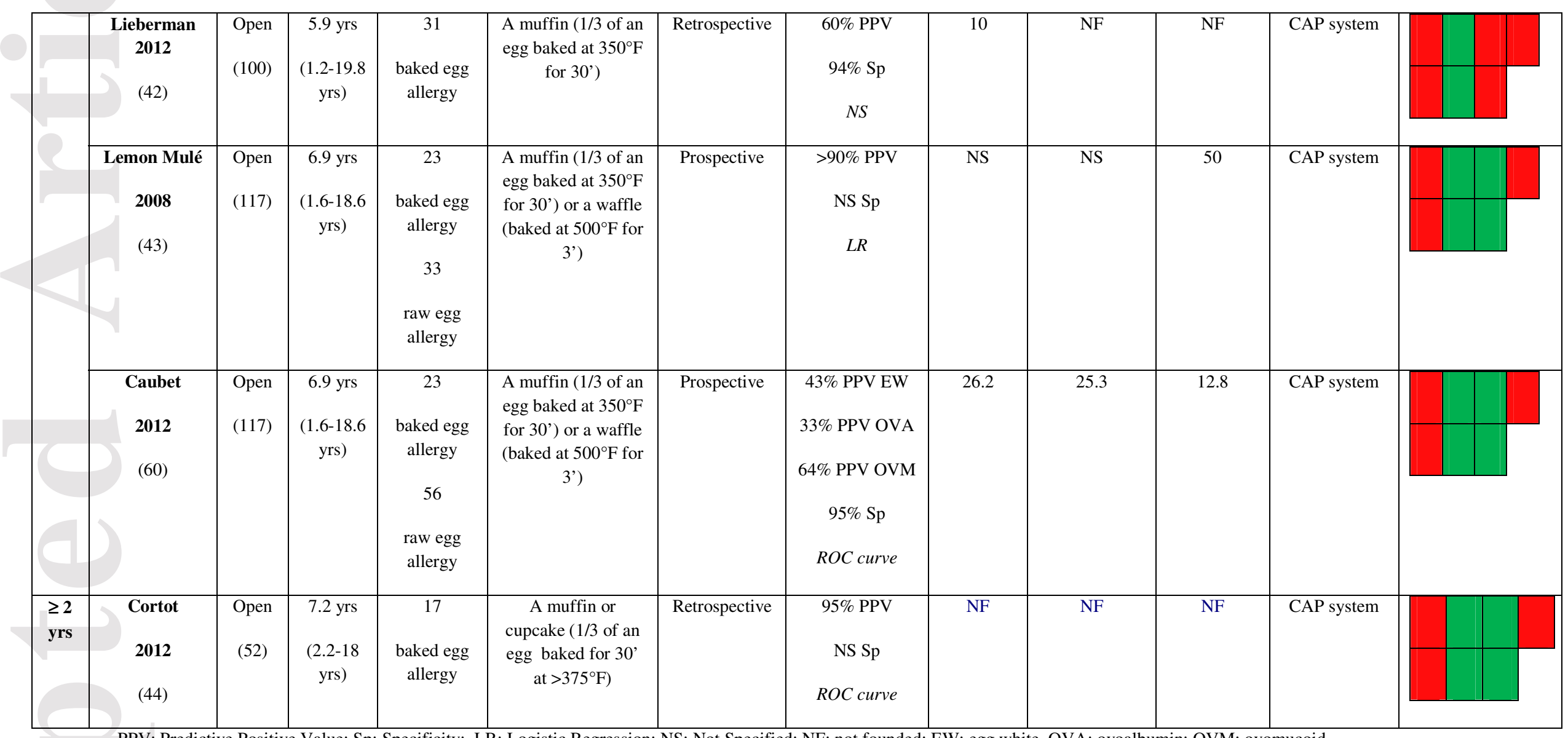

PPV: Predictive Positive Value; Sp: Specificity; LR: Logistic Regression; NS: Not Specified; NF: not founded; EW: egg white, OVA: ovoalbumin; OVM: ovomucoid

This article is protected by copyright. All rights reserved. 
Table 7 - Practical clinical indications. Cut-offs proposed by the methodologically best studies

\section{A: Raw egg}

\begin{tabular}{|l|l|l|l|l|}
\hline Raw egg (Skin Prick Test) & $<2$ years & Ref & Ref \\
\hline $\begin{array}{l}\text { Raw egg (Commercial } \\
\text { extract) }\end{array}$ & $\begin{array}{l}\text { SPT }=4 \mathrm{~mm} \text { wheal } \\
(95 \% \mathrm{PPV})\end{array}$ & $\begin{array}{l}\text { Peters } 2013 \\
(16)\end{array}$ & $\begin{array}{l}\text { SPT }=10 \mathrm{~mm} \text { wheal } \\
(95 \% \mathrm{Sp})\end{array}$ & $\begin{array}{l}\text { Vazquez- Ortiz } \\
2014(35)\end{array}$ \\
\hline Raw egg (PbP) & - & - & $\begin{array}{l}\text { PbP }=14 \mathrm{~mm} \\
\text { wheal (95\% PPV) }\end{array}$ & Mehl 2006 (12) \\
\hline $\begin{array}{l}\text { Ovoalbumin (Commercial } \\
\text { extract) }\end{array}$ & - & - & $\begin{array}{l}\text { SPT }=10 \mathrm{~mm} \text { wheal } \\
(95 \% \mathrm{Sp})\end{array}$ & $\begin{array}{l}\text { Vazquez- Ortiz } \\
2014(35)\end{array}$ \\
\hline $\begin{array}{l}\text { Ovomucoid (Commercial } \\
\text { extract) }\end{array}$ & - & - & $\begin{array}{l}\text { SPT }=8.5 \mathrm{~mm}(95 \% \\
\text { Sp) }\end{array}$ & $\begin{array}{l}\text { Vazquez- Ortiz } \\
2014(35)\end{array}$ \\
\hline
\end{tabular}

\begin{tabular}{|l|l|l|l|l|}
\hline Raw Egg (sIgE) & $<2$ years & Ref & $>2$ years & Ref \\
\hline Raw egg & $\begin{array}{l}\text { sIgE }=1.7 \mathrm{kU}_{\mathrm{A}} / \mathrm{L} \\
(95 \% \mathrm{PPV})\end{array}$ & $\begin{array}{l}\text { Peters } 2013 \\
(16)\end{array}$ & $\begin{array}{l}\mathrm{sIgE}=3.6 \mathrm{kU}_{\mathrm{A}} / \mathrm{L} \\
(95 \% \mathrm{PPV})\end{array}$ & $\begin{array}{l}\text { Vazquez- Ortiz } \\
2014(35)\end{array}$ \\
\hline & & & $\begin{array}{l}\mathrm{sIgE}=6 \mathrm{kU}_{\mathrm{A}} / \mathrm{L} \\
(95 \% \mathrm{PPV})\end{array}$ & $\begin{array}{l}\text { Sampson } 2001 \\
(53)\end{array}$ \\
\hline & & & $\begin{array}{l}\mathrm{sIgE}=7.3 \mathrm{kU} / \mathrm{L} \\
(95 \% \mathrm{PPV})\end{array}$ & Ando 2001 (52) \\
\hline
\end{tabular}

\section{B: Heated egg:}

\begin{tabular}{|l|l|l|l|l|}
\hline $\begin{array}{l}\text { Heated egg (Skin Prick } \\
\text { Test) }\end{array}$ & $<2$ years & Ref & 2 years & Ref \\
\hline $\begin{array}{l}\text { Raw egg (Commercial } \\
\text { extract) }\end{array}$ & $\begin{array}{l}\text { SPT = 5 mm wheal } \\
(100 \% \mathrm{Spec})\end{array}$ & $\begin{array}{l}\text { Sporik } 2000 \\
(38)\end{array}$ & $\begin{array}{l}\text { SPT }=11 \mathrm{~mm} \\
\text { wheal }(95 \% \mathrm{Sp})\end{array}$ & $\begin{array}{l}\text { Vazquez- Ortiz } \\
2014(35)\end{array}$ \\
\hline $\begin{array}{l}\text { Ovoalbumin (SPT } \\
\text { commercial extract) }\end{array}$ & - & $\begin{array}{l}\text { SPT }=10.5 \mathrm{~mm} \\
\text { wheal }(95 \% \mathrm{Sp})\end{array}$ & $\begin{array}{l}\text { Vazquez- Ortiz } \\
2014(35)\end{array}$ \\
\hline $\begin{array}{l}\text { Ovomucoid (SPT } \\
\text { commercial extract) }\end{array}$ & - & $\begin{array}{l}\text { SPT }=13 \mathrm{~mm} \text { wheal } \\
(95 \% \mathrm{Sp})\end{array}$ & $\begin{array}{l}\text { Vazquez- Ortiz } \\
2014(35)\end{array}$ \\
\hline
\end{tabular}

PPV: Predictive Positive Value; Sp: Specificity.

This article is protected by copyright. All rights reserved. 
Figure 1 - Flow chart of the search run to obtain the studies included in the present review (SPT: Skin Prick Tests; IgEs: specific serum IgEs)

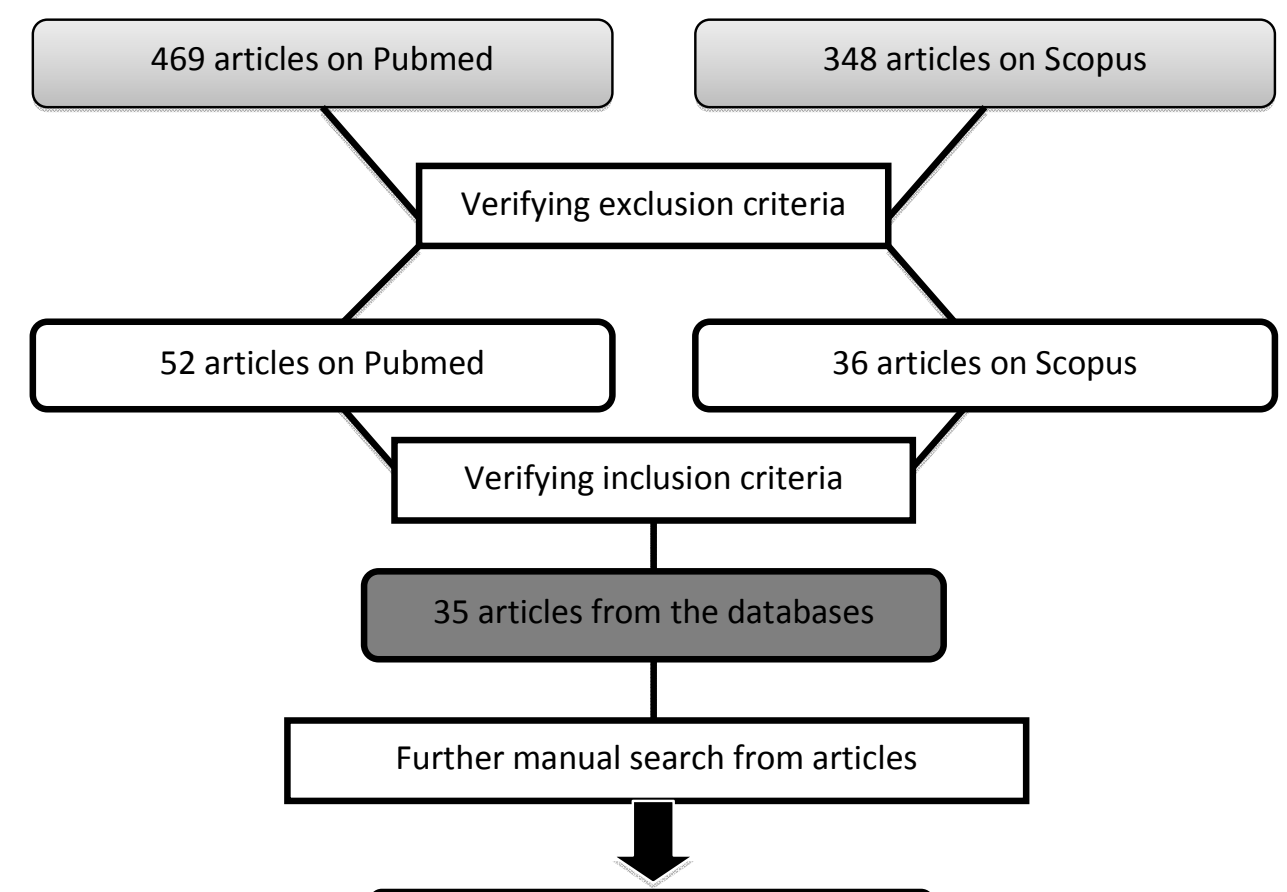

\section{7 articles included}

\section{9 articles for SPTs}

- 6 articles on raw egg $(11,12$, $16,35,36,37$ )

- 2 articles on heated egg (35, 38)

- 9 articles on baked egg $(16,39$, $40,41,42,43,44,45,46)$

- 4 articles excluded since no differentiation was made between raw, heated and
- 14 articles on raw egg $(9,12$, $16,35,36,37,47,48,49,50$, $51,52,53,54)$

- 5 articles on heated egg (35, $52,55,56,57)$

- 7 articles on baked egg $(41,42$, $43,44,58,59,60$ )

- 6 articles excluded since no differentiation was made between raw, heated and baked egg $(29,30,31,32,33$,

This article is protected by copyright. All rights reserved. 
Figure 2 - Risk of bias and applicability concerns graph: authors' judgments about each domain presented as percentages in included studies.

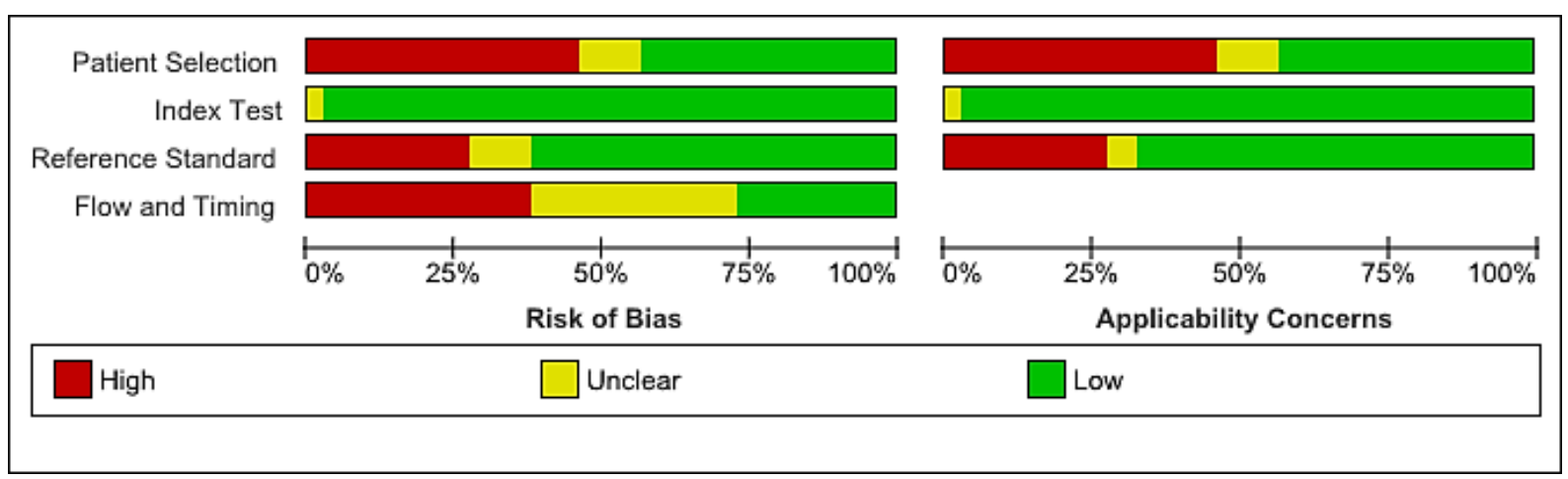

Review Manager (RevMan) [Computer program]. Version 5.3. Copenhagen: The Nordic Cochrane Centre, The Cochrane Collaboration, 2014.

This article is protected by copyright. All rights reserved. 